\title{
DETERMINAÇÃO DA EROSIVIDADE DAS CHUVAS DE CARUARU-PE: 1. CORRELAÇÃO COM PERDAS DE SOLO 2. DISTRIBUIÇÃO E PROBABILIDADE DE OCORRENCIA
}

\author{
ABEL WASHINGTON DE ALBUQUERQUE \\ Engenheiro Agrônomo
}

Orientador: Prof. Dr. JULIO VASQUES FILHO

Dissertação apresentada à Escola Superior de Agricultura "Luiz de Queiroz", da Universidade de São Paulo, para obtenção do título de Mestre em Agronomia, Area de Concentração: Solos e Nutrição de Plantas.

P I R A C I C A B A

Estado de São Paulo - Brasil

Dezembro - 1991 
Ficha catalográfica preparada pela Seção de Livros da Divisão de Biblioteca e Documentação - PCAP/USP

Albuquerque, Abel Washinthon de

A345d Determinação da erosividade das chuvas de Caruaru-PE= 1- Correlação con perdas de solo 2. Distribuição e probabí lidade de ocorrência. Piracicaba, 1991.

p. ilus.

Diss.(Mestre) - ESALQ

Bibliografia.

1. Chuva - Erosividade - Caruaru, PE 2. Erosão - Chuva Correlação 3. Solo - Erosividade - Indice 4. Solo - Perda Efeito de chuva I. Escola Superior de Agricultura Luĩz de Queiroz, Piracicaba

CDD 631.45 


\section{DETERMINAÇÃO DA EROSIVIDADE DAS CHUVAS DE CARUARU-PE: 1. CORRELAÇÃO COM PERDAS DE SOLO 2. DISTRIBUIÇÃO E PROBABILIDADE DE OCORRENAIA}

\section{ABEL WASHINGTON DE ALBUQUERQUE}

Aprovada em: 03/02/1992

Comissão Julgadora :

Prof. Dr. Julio Vasques Filho

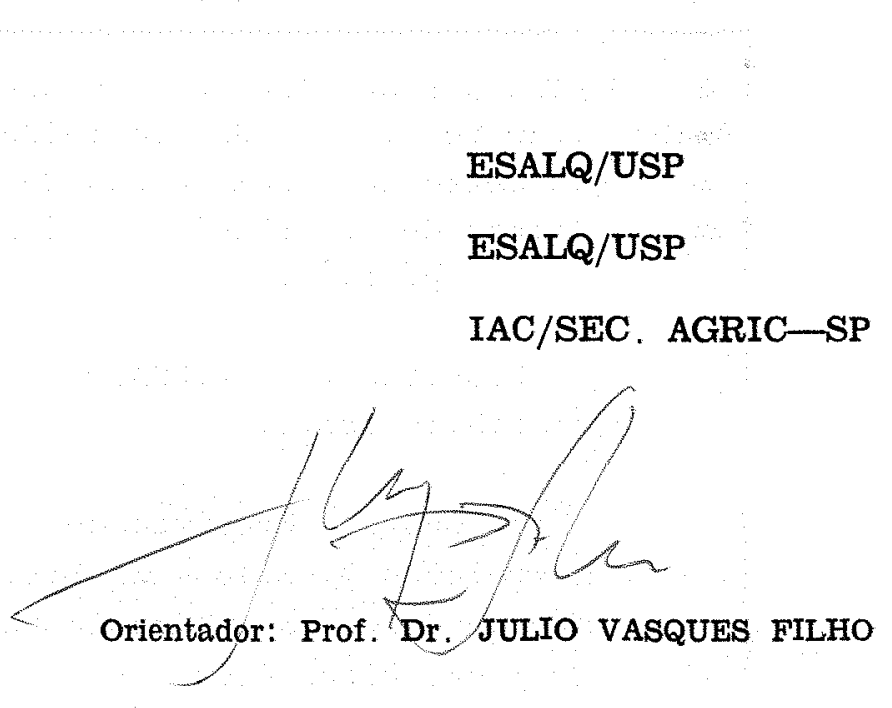

Prof. Dr. Décio Eugênio Cruciani

Dr. Lombardi Neto Filho

P I R A C I C A B A

Estado de são Paulo - Brasil

Dezembro - 1991 
A minha esposa Cicera e aos meus filhos, Gustavo e Rizia, que nos momentos mais dificeis me deram a motivação necessaria para a conclusão deste trabalho.

\section{O F E E C O}

A DEUS por manter em minha vida os sentimentos da esperança, perseverança e fé, sem os quais as barreiras encontradas não seriam ultrapassadas 


\section{A G R A D E C I M E N T O S}

Gostaria de expressar os meus mais sinceros agradecimentos as seguintes pessoas e intitiuções:

- A Universidade Federal de Alagoas que me possibilitou a oportunidade da realização do mestrado.

- A Escola Superior de Agricultura "Luiz de Queiroz" pelo ensinamentos recebidos.

- Ao Prof. Dr. Júlio Vasques Filho cuja orientação foi de suma importância para a concretização deste trabalho.

- Ao Prof. Dr. Iêdo Chaves pela co-orientação deste trabalho.

- Aos colegas Prof. José Carlos Lira e Prof. José Paulo Vieira pelo apoio e incentivo.

- Aos Prof. Dr. Paulo Vanderlei e Prof. Geraldo Verissimo pela orientação estatistica.

- Ao Instituo de Pesquisa Agropecuaria de Pernambuco pela concessão dos dados de chuva e perda de solo, especialmente ao corpo técnico do setor de Agrometerologia e Fertilidade do solo.

- Aos amigos de Pós-Graduação Formagio e Mauricio pela amizade e apoio.

- Aos funcionários do Nucleo de Processamento de Dados da U.F.AL (NPD) pelo apoio técnico.

- Ao meu amigo Dr. Osmair Lacerda pela amizade e orientações dadas 
LISTA DE FIGURAS.......................

IISTA DE TABELAS.....................

RESUMO............................... $x i$

SUMMARI..............................

1. INTRODUÇÃo. .......................... 1

2. REVISÃo DE IITERATURA..................... 4

2.1. Desemsolvimento da equação universal de 4 perdas de solo...................... 4

2.2. Caracteristicas físicas das chuvas e sua relação com as perdas de solo............

2.2.1. Precipitação pluviométrica (P).....

2.2.2. Intensidades máximas (In) ........

2.2.3. Energia cinética total (ECT), Energia cinética de segmentos de intensidade constante igual ou superior a 10 e $25 \mathrm{~mm} / \mathrm{h}$ respectivamente $(\mathrm{KE}>10 \mathrm{e}$ $\mathrm{KE}>251 \ldots \ldots \ldots \ldots \ldots \ldots \ldots \ldots \ldots \ldots \ldots \ldots \ldots \ldots \ldots \ldots$

2.2.4. Produto da energia cinética total pelas intensidades máximas (Ec.In) ...

2.2.5. Produto da precipitação pluviométrica total pelas intensidades máximas $(\mathrm{P}, \mathrm{In}) \ldots \ldots \ldots \ldots \ldots \ldots \ldots \ldots \ldots$ 
Página

2.3. Estimativa do índice de erosividade a partir de dados pluviométricos................

3. MATERIAL E MÉtOdo........................ 34

3.1. Material utilizado................... 34

3.1.1. Localização da área experimental..... 34

3.1.2. Descrição do clima e do solo........ 34

3.1 .2 .1$. Clima............... 34

3.1 .2 .2 . Solo................ 35

3.1.3. Pluviógrafo e pluviômetros......... 35

3.1.4. Ficha para a leitura dos pluviogramas e cálculo da erosividade das chuvas. 36

3.1.5. Descrição da parcela experimental e dos coletores de solo e enxurrada.... 36

3.1.6. Programas para microcomputadores..... 38

3.2. Métodos utilizados.................... 38

3.2.1. Critérios utilizados para separar chuvas erosivas.....................

3.2.2. Determinação dos segmentos de intensidade uniforme das chuvas erosivas....... 38

3.2.3. Determinação das características das chuvas erosivas..................

3.2.3.1. Precipitação pluviométrica total de chuva (P) $\ldots \ldots \ldots \ldots \ldots \ldots \ldots$ 
3.2.3.3. Energia cinética total (ECT)...

3.2.3.4. Produto da energia cinética total pelas intensidades máximas $(E I n) \quad \ldots \ldots \ldots \ldots \ldots \ldots \ldots$

3.2.3.5. Produto da precipitação pluviométrica total de chuvas pelas intensidades máximas (PIn) ....

3.2.3.6. Energia cinética de segmentos de chuva com intensidade constante igual ou maiores do que 10 e $25 \mathrm{~mm} / \mathrm{h} \quad(\mathrm{KE}>10$ e KE $>25$ respectivamente) ........

3.2.4. Coleta do material erodido........ 45

3.2.5. Manejo da parcela experimental.....

3.2.6. Correlação entre características físicas das chuvas erosivas e perdas de solo ................

3.2.7. Distribuição do Índice de erosividade EI30 (Fator "R")................

3.2.7.1. Determinação do índice de erosividade mensal........

3.2.7.2. Determinação do índice de erosividade médio mensal....

3.2.7.3. Determinação do Indice de erosividade estacional..... 
3.2.7.4. Determinação do índice de erosividade anual.........

3.2.7.5. Determinação do índice de erosividade médio anual (Fator "R" da equação universal de perdas de solol .....

3.2.7.6. Determinação da curva de distribuição do índice de erosividade EI30.........

3.2.8. Probabilidade de ocorrência e período de retorno dos valores do Indice de erosividade anual.........

3.2.9. Estimativa do Indice de erosividade médio mensal através de correlações com dados pluviométricos...........

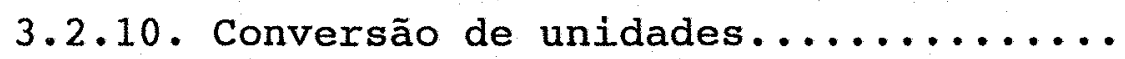

4. RESULTAdOS E DISCUSSõES..................

4.1. Correlações.

4.1.1. Correlações entre características físicas das chuvas erosivas e

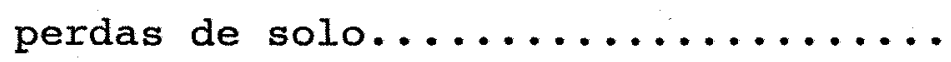

4.2. Distribuição do índice de erosividade EI30 e da precipitação. 
Página

4.2.1. Distribuição do índice de erosividade anual e médio anual.............

4.2.2. Distribuição mensal e estacional do Indice de erosividade...........

4.2.3. Distribuição da precipitação pluviométrica $\ldots \ldots \ldots \ldots \ldots \ldots \ldots \ldots$

4.2.4. Curva de distribuição do índice de erosividade EI30..............

4.2.5. Probabilidade de ocorrência e período de retorno dos valores do índices de erosividade anual..............

4.3. Estimativa do indice de erosividade médio mensal a partir de dados pluviométricos....

5. CONCLUSÕES

6. REFERÊNCIAS BIBLIOGRÁFICAS ..............

7. APENDICE .......................... 
LISTA DE FIGURAS

FIGURA

Página

Nㅡㅇ

01 Pluviograma do tipo IH onde foram cotadas as chuvas individuais erosivas $\ldots \ldots \ldots \ldots \ldots$

02 Ficha para leitura dos pluviogramas e cálculo da erosividade das chuvas..............

03 Histograma de distribuição dos valores percentuais do índice de erosividade médio anual e da precipitação média anual de Caruaru-Pe, correspondente ao período de 1970 a $1989 \ldots \ldots \ldots \ldots \ldots \ldots \ldots \ldots \ldots \ldots \ldots \ldots \ldots \ldots \ldots$

04 Histograma de distribuição dos valores do Índice de exosividade EI30 médio mensal e da precipitação média mensal de Caruaru-Pe, correspondente ao período de 1970 a $1980 \ldots$.

05 Curva de distribuição das percentagens acumulativas dos valores médios mensais do Indice de erosividade EI30 de Caruaru-Pe, correspondente ao período de 1970 a 1989.

06 Curva de distribuição de probabilidade de ocorrência dos valores do índice de erosividade anual (MJ. $\mathrm{mm} / \mathrm{ha} \cdot \mathrm{h}$. ano) de Caruaru-Pe, correspondente ao período de

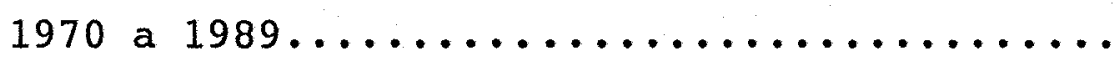




\section{LISTA DE TABELAS}

TABELA

Página

Nㅡㅇ

01 Coeficiente linear (a), de regressão (b) e de correlação das equações de regressão linear simples entre as características físicas das chuvas e perdas de solo.......

02 Valores mensais, médios mensais, anuais e médio anual do Indice de erosividade EI30 (MJ.mm/ha.h) de Caruaru -Pe, correspondente ao período de 1970 a $1989 \ldots \ldots \ldots \ldots \ldots \ldots$

03 Valores da pluviometria total anual e pluviometria utilizada no cálculo do Índice de erosividade médio anual.......

04 Valores percentuais mensais e estacional do Índice de erosividade médio anual, precipitação média anual de Caruaru-Pe, correspondente ao período de 1970 a $1989 \ldots$

05 Valores mensais, médios mensais, anual e médio anual da precipitação pluviométrica de Caruaru-Pe, correspondente ao periodo de

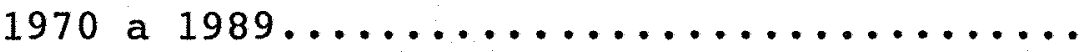


06 Probabilidade de ocorrência e período de retorno (ano) dos valores dos índices de erosividade anual (MJ.mm/ha.h.ano) de Caruaru-Pe, correspondente ao período de

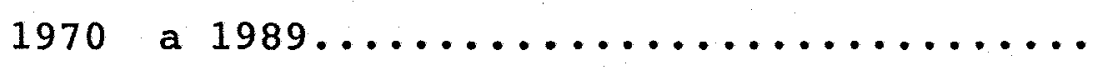

07 Valores correspondente ao índice de erosividade médio mensal, coeficiente de chuva e Indice de erosividade médio mensal estimado....................... 
DETERMINAÇÃo DA EROSIVIVIDADE DAS CHUVAS DE

CARUARU-PE: 1. CORRELAÇÃO COM PERDAS DE SOLO

2. DISTRIBUIÇño E PROBABILIDADE DE OCORRÊNCIA

\section{Autor: ABEL WASHINGTHON DE ALBUQUERQUE \\ Orientador: Prof. Dr. JÚLIO VASQUES FILHO}

RESUMO

A viabilização do uso da equação universal de perdas de solo no estado de Pernambuco requer a existência de valores do indice de erosividade melhor ajustados as condições locais. Visando estabelecer um índice de erosividade que melhor expresse a sua capacidade potencial de causar erosão é que foram estudadas correlacões entre 19 características das chuvas e perdas de solo provocadas por chuvas erosivas. As características da chuva que foram testadas como indice de erosividade são as seguintes: (P) Precipitação total em mm, (ECT) energia cinética total em $\mathrm{MJ} / \mathrm{ha} ;(\mathrm{KE}>10$ e $\mathrm{KE}>25)$ energia cinética considerados apenas segmentos de chuva de intensidades constantes iguais ou superiores a 10 e $25 \mathrm{~mm} / \mathrm{h}$ em $\mathrm{MJ} / \mathrm{ha} ;$ (In) intensidades máximas em $5,10,15,30$ e 60 minutos em mm/h, (EIn) produto da energia cinética total pelas intensidades máximas em 5 , 10, 15, 30 e 60 minutos em MJ.mm/ha.h, (PIn) Produto da precipitação total pelas intensidades máximas em 5, 10, 15, 30 e $60 \mathrm{~min} \mathrm{em} \mathrm{mm}^{2} / \mathrm{h}$. 
As correlações obtidas entre características fisicas de chuvas erosivas e perdas de solo, indicam que a característica da chuva PI60 é a que melhor se correlaciona com as perdas de solo. ( $r=0,6289$ : o maior valor obtido em termos absolutos) Entretanto a aplicação do teste de homogeneidade, indicou não haver diferença estatística entre as características $\operatorname{PI} 60(r=0,6289)$ e energia cinética total $(r=0,4095)$, por conseguinte não existindo diferença entre as características PI60 ( $r=0,6289$ ) e EI30 $(r=0,6161)$. A constatação deste fato indica que a diferença entre as características PI60 e EI30 é meramente devida ao acaso, e por conseguinte o parâmetro EI30 ( $r=0,6161)$ pode ser indicado como índice de erosividade da mesma forma que o $\operatorname{PI60}(x=0,6289)$

o valor médio anual do índice de erosividade EI30 obtido para Caruaru-Pe no período de 1970 a 1989 foi de $2086 \mathrm{MJ} \cdot \mathrm{mm} / \mathrm{ha} \cdot \mathrm{h}$. ano, sendo que se pode esperar que ocorra um valor igual ou maior a esse a cada 2,4 anos ou seja a probabilidade desse valor ser igualado ou superado é de $41,6 \%$. Os valores do índice de erosividade anual que podem ser esperados para os periodos de $2,5,20$ e 100 são os seguintes: 1852 , 2777, 4097 e 5703 MJ.mm/ha.h.ano respectivamente.

o trimestre de fevereiro, março e abril é o de maior risco de erosão, visto que nele ocorre $65 \%$ do valor do Índice de erosividade médio anual e 38\% de precipitação média 
anual. Portanto medidas preventivas de controle da erosão devem ser tomadas principalmente neste periodo no sentido de evitar elevadas perdas de solo.

o estudo de correlação entre os dados do Índice de erosividade médio anual e os dados pluviométricos resultou na obtenção de um baixo valor para o coeficiente de correlação $(r=0,6121)$, o que indica que a equação de regressão é insatisfatória para estimar o índice de erosividade médio anual para locais com condições climáticas semelhantes as de Caruaru-PE, mas que sejam desprovidos de pluviógrafos. 
xvi

EROSIVITY RAINFALL DETERMINATION AT CARUARU-PE:

1. CORRELATION WITH SOIL LOSSES 2. DISTRIBUTYON AND OCURRENCE PROBABILITY

Author: ABEL WASHINGTHON DE ALBUQUERQUE

Adviser: Prof. Dr. JULIO VASQUES FIIHO

\section{SUMMARY}

The viability of using the Universal Soil Losses Equation in Pernambuco state require the existence of erosivity index values better adjusted to local conditions. Trying to establish an erosivity index that can better express its potencial capability to cause erosion, there were studied correlation among 19 rain characteristics and soil losses brought by erosive individual rains. The rain characteristics tested as erosion index are: (P) total precipitation in $\mathrm{mm}$, (KE) total kinetic energy in $\mathrm{MJ} / \mathrm{ha}$, (KEn) $\mathrm{KE}>10 \mathrm{e} \mathrm{KE}>25$ in $\mathrm{MJ} / \mathrm{ha}$, (In) I5, I10, I15, I30, I60 in mm/h, (EIn) EI5, EI10, EI15, EI30, EI60 in Mj.mm/ha.h, (PIn) PI5, PI10, PI15, PI30, and PI60 in $\mathrm{mm}^{2} / \mathrm{h}$.

The correlation obtained among erosive individual rains characteristics and soil losses, show in absolute therms that the chacaracteristics of the PI60 rain $(r=0.6289)$ is the one that is better correlated to the soil losses. However, the aplication of the homogenity test, 
showed that there is no estatistic difference between PI60 $(r=0.6289)$ and EI30 ( $r=0.6161)$ characteristics. This fact constation show that the difference in absolute therme among the PI60 ande EI30 characteristics is merely due to harzard and, consequently, the EI30 $(0.6161)$ parameter can be indicated as erosivity index as the PI60 $(r=0.6289)$.

The year medium value of the erosion index EI30 obtained to Caruaru-PE during the period of 1970 to 1989 was $2086 \mathrm{MJ} . \mathrm{mm} / \mathrm{ha} \cdot \mathrm{h}$.year and can be expected the ocurrence an equal or bigger value than this every 2.4 year or, be it the possibility that this value to be bigger is $41.6 \%$. the year erosion index values that can be expected for the periods 2, 5, 20 and 100 year are: 1852, 2777, 4097 and 5703 MJ.mm/ha.h.year, respectively.

The February, March and April trimester is the one with erosion highest risk because during this time occurs $65 \%$ of the medium year erosion index value and $38 \%$ of the average annal precipitation. So, specialmente during this period preventive measures of erosion control must be taken to that no occur high soil losses.

The study correlation among the average annual erosion index data and pluviometric data resulted in a low value to the correlation coeficiente $(r=0.6121)$, which shows that the regression equation isn't good estimed the average annual erosion index for place with the same clima conditions as Caruaru-PE, but where there are no pluviographs. 


\section{INTRODUÇÃO}

A zona do Agreste de Pernambuco é caracterizada por uma agricultura intensiva, que associada a chuvas erosivas e solos de alta erodibilidade tem proporcionado graves problemas de erosão e por conseguinte - declínio da produtividade dos seus solos.

No inicio da década de 1950 a Indústria de alimentos Peixe S.A, preocupada com o problema da erosão nesta região do estado de Pernambuco, instalou os primeiros trabalhos de pesquisa sobre manejo e conservação do solo no municipio de Pesqueira. Os trabalhos de pesquisa tinham como objetivo medir as perdas de solo e água causadas pela chuva em parcelas submetidas a diferentes tipos de preparo do solo e cobertura vegetal.

Posteriormente a Secretaria de Agricultura de Pernambuco, através do Departamento de Defesa do Solo, instalou entre 1954 e 1955 , trabalhos sobre manejo e conservação do solo nos municipios de Gloria do Goitá, Garanhus e Serra Talhada, entretanto os conjuntos medidores de erosão funcionaram apenas durante alguns anos e de forma precária, devido a falta de material e pessoal de apoio. 
A partir de 1966, através de convênios entre o IPA/UFPE/SUDENE, estes trabalhos foram reativados, objetivando avaliar os efeitos de diferentes tipos de cobertura e práticas de manejo do solo sobre as perdas de solo e água e a determinação dos fatores da equação da equação universal de perdas de solo.

- Indice de erosividade EI30 obtido por WISCHMEIER (1958), a partir de correlações entre características físicas das chuvas e perdas de solo para as condições climáticas dos E.U.A não tem tido a mesma precisão en estimar a capacidade potencial da chuva de causar erosão em certos tipos climáticos, mormente naqueles de regiões tropicais. Em função deste fato, tem-se procurado testar o indice de erosividade EI30 juntamente com outros parâmetros da chuva, objetivando encontrar o indice de erosividade que melhor se ajuste às perdas de solo de determinadas condições locais.

A escolha do Indice de erosividade que melhor se ajuste as perdas de solo para cada região do estado de Pernambuco contribuirá para que, através da equação universal de perda de solo, possa se estabelecer em bases técnicas o planejamento do uso e do manejo mais adequado para os solos do Estado.

o presente trabalho pretende atingir os seguintes objetivos: 
a) Determinar um índice de erosividade que melhor se ajuste as condições climáticas de Caruaru-Pe a partir de correlações entre características físicas das chuvas e perdas de solo causada por chuvas erosivas.

b) Determinar $\circ$ valor do indice escolhido para as condições de Caruaru-Pe e sua distribuição anual no transcorrer do período de 1970 a 1989.

c) Determinar a probabilidade de ocorrência e - período de retorno dos valores do índice de erosividade anual.

d) Estimar os valores médio mensal e médio anual do Indice escolhido a partir de correlações com dados pluviométricos.

e) Fornecer informações básicas para a pesquisa e o planejamento conservacionista. 


\section{REVISĨO DE ITTERATURA}

2.1. Desenvolvimento da equação universal de perdas de solo.

A erosão é um fenômeno cujo impacto sobre os recursos naturais renováveis tem preocupado governos e instituições em todo o mundo. A magnitude deste fenômeno tem sido considerada como uma ameaça a própria existência da humanidade. Este risco tem contribuído para que haja em grande parte das nações uma imperiosa necessidade de se controlar de forma racional a erosão.

A necessidade de se determinar uma metodologia capaz de avaliar com precisão os fatores que causam a erosão e a estimativa das perdas de solo causadas pela erosão, tem resultado em intensas pesquisas. Dentre essas tentativas, a mais moderna e precisa é a equação universal de perdas de solo. A determinação da equação universal de perdas de solo, permite a previsão das perdas de solo causadas pela erosão e indica quais são os fatores que exercem os maiores efeitos sobre as perdas de solo. (WISCHIMEIER \& SMITH 1978). 
LAWS \& PARSONS (1940), realizaram pesquisas básicas visando medir o efeito das caracteristicas fisicas das chuvas sobre as perdas de terra. Estes trabalhos marcaram - inicio do conceito de que a erosão é um processo que envolve energia, mormente aquela fornecida pela queda das gotas de chuvas. Os autores estudaram o efeito da velocidade, tamanho de gotas e energia cinética sobre a erosão por salpico.

A partir da década de 1940 foram realizadas as primeiras pesquisas com o objetivo de se obter equações impíricas que estimassem as perdas de terra, mormente na região de Corn Belt nos E.U.A. (SMITH \& WISCHMEIER 1962). ZINGG (1940), relacionou a intensidade de perdas de solo com o grau de declive e com o comprimento de encostas; como resultado o autor obteve uma equação que estimava o efeito do grau de declive e do comprimento de encostas sobre as perdas de solo. Esta equação foi uma das primeiras a tentar quantificar as perdas de solo causadas pela erosão.

Tomando como base a equação de ZINGG (1940), SMITH (1941) desenvolveu uma equação de previsão de perdas de solo, adicionando dois fatores: o efeito das culturas e práticas conservacionistas; além de desenvolver tambem o conceito de tolerância de perdas de solo.

BROWNNING (1947), a partir dos trabalhos de ZINGG (1947) e SMITH (1941), aprimorou as equações anteriores 
adicionando os fatores erodibilidade e manejo do solo. Sob a coordenação de Musgrave, a comissão nacional de previsão de perdas de solo (E.U.A), após a avaliação de todos os dados de perdas de solo dos E.U.A até 1946, reavaliou os fatores das equações anteriores $e$ ao mesmo tempo adicionou um fator chuva. O fator chuva foi obtido a partir de estudos de correlação entre perdas de solo e o fator P30 (Quantidade de chuva ocorrida em um período de 30 minutos). (MUSGRAVE, 1947).

A equação de Musgrave foi utilizada por uma década nos E.U.A, sendo substituída na década de 1950 pela equação universal de perda de solos desenvolvida por WISCHMEIER \& SMITH (1958).

A equação de predição de perda de solo como atualmente tem sido utilizada foi desenvolvida a partir de 1953, quando o Soil And Water Conservation Research Division of The Agricultural Research Service, reuniu na Universidade de Purdue dados de escorrimento supercial e de perdas de solo de 10.000 parcelas de 48 estações experimentais dos E.U.A. Com base nestes dados foram incluídas inovações importantes que melhoraram a precisão da estimativa de perdas de solo quais sejam: um indice de erosividade da chuva, um método para avaliação dos efeitos do manejo de uma cultura, um método para quantificar a exodibilidade do solo e um método para determinar os efeitos das interações de variáveis como: produtividade, sequência de culturas e manejo dos 
resíduos culturais. As inovações introduzidas possibilitaram que as dificuldades em se considerar fatores de natureza climática ou geográfica existente nas primeiras equações fossem superadas, permitindo a sua aplicação em qualquer lugar onde os dados para o seu cálculo pudessem ser obtidos, sendo por isso chamada de equação universal de perdas de solo. (WISCHMEIER \& SMITH, 1978).

A partir de sua consolidação nas condições dos E.U.A, a equação universal de perdas de solo passou a ser utilizada largamente no planejamento conservacionista, tanto em seu pais de origem como em muitos outros países do mundo.

A equação é constituída pelos principais fatores que causam a erosão hídrica, sendo que o produto de todos os fatores resultará na estimativa das perdas de solo

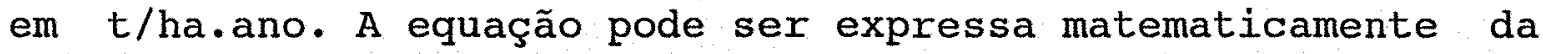
seguinte forma:

$$
\mathrm{A}=\mathrm{R} \cdot \mathrm{K} \cdot \mathrm{L} \cdot \mathrm{S} \cdot \mathrm{C} \cdot \mathrm{P},
$$

onde:

$$
\begin{aligned}
& A=\text { Perda média anual de solo ( } t / \text { ha.ano) } \\
& R=\text { Fator erosividade da chuva, expresso por }
\end{aligned}
$$
um Indice numérico que estima a capacidade da chuva de provocar erosão.(Mj.mm/ha.h.ano) .

$\mathrm{K}$ = Fator erodibilidade do solo, respresenta a susceptibilidade do solo a erosão e é expresso numericamente pela relação entre a perda média anual de solo e o fator erosividade da chuva de uma parcela padrão com as 
seguintes condições: 98 de declividade, $25 \mathrm{~m}$ de comprimento e mantida continuamente sem combertura vegetal e cultivada morro abaixo de forma a manter a superfície do solo livre de crostas. (t.ha.h/ha.Mj.mm)

$I=$ Fator comprimento do declive, que é a relação de perdas de solo entre uma encosta com um certo comprimento e outra com $25.0 \mathrm{~m}$, sendo as demais condições iguais.

$S$ = Fator grau de declive, que é a relação de perdas de solo entre uma encosta com um certo declive e outra com 9\% de declividade, sendo as demais condições iguais.

$C=$ Fator uso e manejo, que é a relação de perdas de solo entre um solo cultivado com uma determinada cultura e um solo mantido constatemente sem cobertura, isto é, nas mesmas condições de avaliação do fator $\mathrm{K}$

$\mathrm{P}$ = Fator prática conservacionista, que é a relação de perdas de solo entre um solo com uma determinada prática de controle da erosão e um solo sem prática conservacionista.

A equação universal de perdas de solo permite isolar e medir cada fator separadamente. Sua vocação e finalidade principal é orientar a escolha da melhor técnica de conservação do solo e da água para determinadas condições específicas. (LEPRUN 1981).

A equação universal de perdas de solo tem sido 
utilizada largamente no Nordeste, particularmente nos convênios estabelecidos pela SUDENE, que objetivavam o desenvolvimento de programas de conservação do solo adequados a região Nordestina. (LEPRUN 1981).

Dentre os fatores da equação universal de perdas de solo o fator " $R$ " tem sido considerado como um dos mais importantes, não só pela sua capacidade em medir os efeitos do impacto das gotas de chuva e turbulência combinados com a capacidade de transporte da enxurrada, como também por ser utilizado nos cálculos dos fatores " $K " \mathrm{e}$ "C". (LEPRUN 1981)

\subsection{Características físicas das chuvas e sua relação com as perdas de solo.}

o conceito de que o processo erosivo é um fenômeno que envolve energia foi fundamental para que as suas causas fossem compreendidas de forma ampla e defenitiva. 0 conceito da erosão como um processo que envolvia energia só foi possível a partir de pesquisas básicas sobre caracteristicas físicas das chuvas tais como: intensidade, momento, energia cinética, velocidade, tamanho e massa das gotas de chuva. (LAWS \& PARSONS 1943).

Os trabalhos de LAWS \& PARSONS (1943), foram reiniciados após 1944 por ELIISON (1944); ROSE (1960); WISCHMEIER \& SMITH (1958) e HUDSON (1961) • 
ELLISON (1944), pesquisou em condições de laboratório o efeito do tamanho, velocidade $e$ intensidade das gotas de chuva sobre a erosão por salpico. Os dados obtidos possibilitaram o autor concluir que a erosão era diretamente proporcional as seguintes características físicas da chuva : velocidade das gotas, tamanho das gotas e a intensidade.

HUDSON (1973), definiu a erosividade da chuva como a sua capacidade potencial de causar erosão, sendo portanto uma função das características físicas da chuva. o autor ressalta que a amplitude de variação das características físicas das chuvas, associada as suas múltiplas formas e combinações tornam a mensuração da erosividade muito complexa. $O$ autor acrescenta que a erosividade da chuva é um índice numérico que expressa a capacidade da chuva de provocar erosão.

\subsubsection{Precipitação total (P)}

Analizando dados de perdas de solo de 8.250 arcelas anuais de 25 estações experimentais dos E.U.A, WISCHMEIER \& SMITH (1958), estabeleceram correlações entre perdas de solo e características físicas das chuvas com o objetivo de encontrar a características que melhor estimasse a erosividade da chuva. Com relação as correlações entre perda de solo e quantidade de chuva os autores relatam que em geral os coeficientes de correlação foram baixos. 
LAL (1976), estudando a relação entre várias características da chuva e perdas de solo em parcelas descobertas de um Alfisol com declives de 1, 5, 10 e $15 \%$, obteve para a precipitação pluviométrica total os seguintes coeficientes de correlação: $r=0,58,0,72,0,68$ e 0,71 respectivamente.

LOMBARDI NETO (1977), correlacionando características físicas da chuva com perdas de solo, correspondente a um período de 15 anos de dados de chuva de Campinas-SP, constatou que houve baixa correlação entre quantidade de chuva e perdas de solo $(x=0,44)$

FOSTER et alii (1982), correlacionando 21 características da chuva com perdas de solo para 10 locais do E.U.A e 1 local do Brasil, constataram que a quantidade de chuva apresentou uma baixa correlação com as perdas de solo $(r=0,14$ a 0,53$)$.

MORAIS (1986), correlacionando características físicas das chuvas com perdas de solo para três locais do Rio Grande do Sul, constatou que a precipitação pluviométrica total apresentou baixos coeficientes de correlação quando correlacionada com perdas de solo. $(r=0,631$ para Guaíba, $r=0,547$ para $I j u i ́$ e $r=0,583$ para Santa Maria).

CARVALHO correlacionando características físicas das chuvas com perdas de solo de Mococa-SP, constatou que a precipitação total apresentou em 
termos absolutos um coeficiente de correlação mais baixo do que a energia cinética $(x=0,6617$ e $x=0,7306$ respectivamente). 0 autor constatou também não haver diferença significativa entre os coeficientes de correlação da energia cinética total e precipitação total.

\subsubsection{Intensidades máximas $(\mathrm{In})$}

BARNETT (1958), correlacionou perdas de solo com características físicas da chuva tais como: quantidade, duração, intensidades máximas, tempo de ocorrência, enxurrada e umidade antecedente do solo. o autor constatou que a intensidade máxima da chuva em $60 \mathrm{~min}$ foi o índice que melhor se correlacionou com as perdas de solo $(r=0,768)$. O autor concluiu que a ocorrência de chuvas de alta intensidade em curtos períodos, era a melhor explicação para a correlação obtida.

WISCHMEIER \& SMITH (1958), estabeleceram correlações entre perdas de solo e características físicas das chuvas para as condições edafoclimáticas dos E.U.A. Os autores constataram que a intensidade máxima em 30 minutos apresentou altas correlações com as perdas de solo.

BERTONI \& PASTANA (1964), analisaram dados de chuva correspondente a um período de 10 anos em quatro estações experimentais de São Paulo, objetivando estabelecer correlações entre diferentes intensidades máximas $(5,10,30$ 
e $60 \mathrm{~min})$ e perdas de solo. Os autores constataram que os coeficientes de correlação entre as diferentes intensidades e perdas de solo foram em geral baixos. Os autores concluiram que os resultados obtidos não foram suficientes para se estabelecer uma equação de regressão que explicasse satisfatoriamente as perdas de solo.

HUDSON (1973), relata que sob condições de fortes chuvas tropicais, ocorre alta proporção de chuvas de baixa intensidade e por conseguinte de baixa energia. o autor conclue que os riscos de perdas de solo estão associadas a chuvas de curta duração e forte intensidade e por conseguinte de alta energia cinética.

GREER (1971), analisando a relação entre diferentes intensidades de chuva e perda de solo para um período de seis anos em parcelas aradas, gradeadas e plantadas com milho, constatou que chuvas excessivas (chuvas com intensidade igual ou maior do que $76,35,25$ e $20 \mathrm{~mm} / \mathrm{h}$, com respectivamente $5,15,30$ e 60 minutos de duração) produziram em torno de $50 \%$ das perdas de solo, durante aproximadamente dois meses, quando nenhum resíduo ou cobertura vegetal protegia o solo. O autor conclue que estas chuvas representam apenas $6 \%$ do total anual das chuvas locais.

LOMBARDI NETO \& PASTANA (1972), analizando dados de chuva de um período de 16 anos, constataram que as chuvas de longa duração e baixas intensidade, resultam em 
pequenas perdas de solo e água, enquanto que as chuvas de curta duração com altas intensidades, resultam em grandes perdas de solo. Os autores concluíram que apenas 20 chuvas por ano nesse período provocaram erosão significativa, representando $10 \%$ da precipitação anual.

LOMBARDI NETO (1977), estabeleceu correlações entre características físicas da chuva e perdas de solo de Campinas-SP. O autor constatou que das características das chuvas, a intensidade máxima em 30 minutos foi a que melhor se correlacionou com as perdas de solo, com um coeficiente de correłação de 0,685 , semelhante ao do índice EI30 (r = $0,672)$.

CARVALHO (1987), correlacionando perdas de solo com diferentes intensidades de chuva obteve coeficientes de correlação que variaram de 0,6441 a 0,7332 para as características da chuva I5 e I50 respectivamente.

HUDSON (1973), constatou que a intensidade a partir da qual as perdas de solo se tornavam significativas era $25,4 \mathrm{~mm} / \mathrm{h}$. Constatou ainda uma alta correlação entre perda de solo e energia cinética, quando se levou em consideração os segmentos uniformes cuja intensidade fosse superior a $25 \mathrm{~mm} / \mathrm{h}$.

2.2.3. Energia cinética total (ECT) e energia cinética de segmentos de chuva com intensidade constante igual ou superiore a 10 e $25 \mathrm{~mm} / \mathrm{h}$ respectivamente (KE $>10$ e $\mathrm{KEE}>25$ ). 
A energia cinética da chuva pode ser mais facilmente computada do que medida. Com $\circ$ conhecimento da velocidade terminal e da massa da gota de chuva a energia cinética das gotas de chuva pode ser facilmente obtida. (SMITH \& WISCHMEIER 1962).

Os principais estudos de correlação entre energia cinética da chuva e erosão indicaram uma estreita correlação. (ELLISON, 1944 ; ROSE, 1960 e SMITH \& WISCHMEIER $1962)$

ROSE (1960), em condições de laboratório, pesquisou o efeito das características físicas das chuvas sobre as perdas de solo e constatou que a desagregação do solo por unidade de área estava mais associada ao momento por unidade de área e tempo do que a energia cinética por unidade de área e tempo.

A partir dos dados de LAWS \& PARSONS (1943), WISCHMEIER \& SMITH (1958), desenvolveram um método para computar a energia cinética da chuva. o método consiste na leitura de pluviogramas com o objetivo de obter-se segmentos sucessivos de intensidade constante de cada chuva individual erosiva. De posse da intensidade medida em $\mathrm{mm} / \mathrm{h}$, calcula-se a energia cinética da chuva utilizando a seguinte equação expressa no Sistema Internacional de Unidades segundo FOSTER et alii (1981).

$$
E=0,119+0,0873 \log _{10} I_{\text {, }}
$$


onde:

$$
\begin{aligned}
& \mathrm{E}=\text { Energia cinética em } \mathrm{MJ} / \mathrm{ha} \cdot \mathrm{mm} ; \\
& I=\text { Intensidade em } \mathrm{mm} / \mathrm{h} .
\end{aligned}
$$

De acordo com LEPRUN (1981), a energia cinética das gotas de chuva na equação de WISCHMEIER \& SMITH (1958), é superior aquelas encontradas em outras partes do mundo. De acordo com o mesmo autor as chuvas de regiões continentais tem energia cinética superior as chuvas de regiões litorâneas, visto que as gotas de chuva são maiores . SMITH \& WISCHMEIER (1962), relatam que para chuvas de grandes intensidades $(>75,0 \mathrm{~mm} / \mathrm{h})$ a curva da energia cinética obtida pelos autores apresenta uma superestimação em comparação com a curva da energia cinética obtida por HUDSON (1963) e esclarecem que provavelmente este fato ocorreu devido a uma estabilização do tamanho médio das gotas em chuvas de alta intensidade.

HUDSON (1963), pesquisando as relações entre distribuição de tamanho de gotas, intensidade e energia cinética para as condições da Rodésia na Africa, constatou a partir de dados de chuvas de alta intensidade $\left(\begin{array}{lll}150 & \text { a } 225\end{array}\right.$ $\mathrm{mm} / \mathrm{h})$, que a energia cinética aumentava rápidamente com o aumento da intensidade até o intervalo de $75-100 \mathrm{~mm} / \mathrm{h}$, permanecendo a partir desses valores quase que constante até intensidades de $225 \mathrm{~mm} / \mathrm{h}$. 
KINNELL (1973), pesquisando as relações entre distribuição de tamanho de gotas, intensidade e energia cinética para três locais dos E.U.A, constatou que houve uma variação nas relações encontradas, sendo esta diferença atribuida ao tipo de chuva e a sua localização geográfica. CARTER et alii (1974), pesquisando as relações entre distribuição de tamanho de gotas, intensidade e energia cinética para dois locais do centro sul dos E.U.A, obtiveram resultados que diferiram daqueles obtidos por LAWS \& PARSONS (1943). Estes autores constataram que a energia cinética aumentava com a intensidade até o intervalo de $50-75 \mathrm{~mm} / \mathrm{h}$, diminuindo até intensidades de $175-200 \mathrm{~mm} / \mathrm{h}$, onde começava a aumentar novamente com $\circ$ aumento da intensidade. CARTER et alii (1974), advertem que os dados de LAWS \& PARSONS (1943), foram extrapolados com o objetivo de obter-se valores para a distribuição de gotas para intensidades de 100 a $150 \mathrm{~mm} / \mathrm{h}$. Acrescentam que WISCHMEIER \& SMITH (1958), também extrapolaram os mesmos dados, ainda mais, com o objetivo de calcular a energia cinética da chuva para intensidades de até $250 \mathrm{~mm} / \mathrm{h}$, resultanto por conseguinte numa superestimação da energia cinética para chuvas de alta intensidade.

ZANCHI \& TORRI (1980), constataram que os valores obtidos para a relação entre energia cinética e intensidade das chuvas obtidos para as condições dos E.U.A, não tiveram a mesma validade para as condições climáticas da 
região central da Itália, onde sobretudo a temperatura teve relevante influência na relação entre distribuição de tamanho de gotas de chuvas e intensidade, resultando portanto em valores diferentes daqueles obtidos nos E.U.A.

CARTER et alii (1974), constataram com relação as chuvas do centro-sul dos E.U.A, que a temperatura do ar, a estação do ano e a duração da chuva foram os principais parâmetros responsáveis pela variação do diâmetro médio das gotas obtido em diferentes intensidades de chuva.

LEPRUN (1984), pesquisando o diâmetro médio das gotas de chuvas da região semi-árida e da região da zona da mata do Nordeste do Brasil, constatou que a relação entre - diâmetro médio das gotas e a intensidade das chuvas é diferente entre as duas regiões.

ROTH et alii (1984), pesquisando a relação entre energia cinética e a intensidade das chuvas para as condições fisiográficas de Londrina-PR, constataram que o diâmetros de gotas de chuva foram em termos médios maiores do que os obtidos em outros países e no Nordeste do Brasil além de verificarem que a relação entre energia cinética e a intensidade das chuvas para chuvas convectivas apresentava dados de energia cinética maiores que os estimados pela equação de WISCHMEIER \& SMITH (1958).

MORAIS (1986), comentando os baixos coeficientes de correlação obtidos entre diferentes índices de erosividade e perda de solo de três locais do Rio Grande 
do Sul, sugere a necessidade de estudos básicos das relações entre distribuição de tamanho de gotas, intensidade e energia cinética das chuvas locais, como forma de melhor estimar a energia cinética e obter um índice de erosividade mais ajustado as condições locais.

HUDSON (1973), obteve para as condições da Rodésia, valores da energia cinética semelhantes aos obtidos por WISCHMEIER \& SMITH (1962), até intensidades de $60 \mathrm{~mm} / \mathrm{h}$., e menores para intensidades de até $120 \mathrm{~mm} / \mathrm{h}$. Deve-se, ressaltar, entretanto, que os valores obtidos por HUDSON (1973), foram obtidos através de métodos diretos, enquanto que os obtidos por WISCHMEIER \& SMITH (1962), para intensidades de até $120 \mathrm{~mm} / \mathrm{h}$, foram obtidos através da extrapolação de dados de vários autores, mormente os de LAWS \& PARSONS (1940).

WISCHMEIER \& SMITH (1958), estabeleceram correlações entre perdas de solo e características físicas das chuvas dos E.U.A com o objetivo de encontrar a características que melhor estimasse a erosividade da chuva. Com relação as correlações entre energia cinética e perdas de solo, os autores constataram que energia cinética estima melhor as perdas de solo do que a quantidade de chuva.

LOMBARDI NETO (1977), correlacionando dados de perdas de solo com característica físicas da chuva de Campinas-SP, constatou que houve baixa correlação entre energia cinética e perdas de solo $(r=0,55)$. 
LAL (1976), correlacionando dados de perda de solo com características físicas da chuva em parcelas descobertas de um Alfisol com declives de $1,5,10$ e 15 , obteve para a energia cinética os seguintes coeficientes de correlação: $\quad r=0,60,0,87,0,88$ e 0,75 respectivamente. MORAIS (1986), correlacionando características físicas das chuvas com perdas de solo para três locais do Rio Grande do Sul, observou que quando considerada isoladamente, a energia cinética foi a característica da chuva que melhor se correlacionou com as perdas de solo, sendo que os coeficientes de correlação linear obtido foi de $r=0,576$ em Ijuí, $r=0,661$ em Santa Maria e $r=0,718$ e, Guaíba.

HUDSON (1973), avaliando a capacidade da chuva de provocar erosão nas condições de clima subtropical da Rodésia, verificou que o Indice EI30 não apresentou a mesma capacidade de estimar as perdas de solo como nas condições climáticas dos E.U.A. Com base neste fato desenvolveu um indice de erosividade baseado na hipótese de que deveria haver um valor crítico de intensidade de chuva a partir do qual as perdas de solo começam a ser significativas. O autor verificou que a energia cinética de segmentos de intensidades iguais ou superiores a $25,4 \mathrm{~mm} / \mathrm{h}$ apresentaram maiores correlação com as perdas de solo, do que qualquer outra características da chuva quando considerada isoladamente. O indice desemvolvido foi denominado de KE>25 
e segundo o autor, para regiões tropicais e subtropicais proporciona um valor preciso na estimativa da erosividade.

Segundo HUDSON (1981), o cálculo do índice KE $>25$, consiste em computar a energia cinética total considerando apenas segmentos de chuva com intensidade maior que $25 \mathrm{~mm} / \mathrm{h}$. Esclarece que $O$ Indice $\mathrm{KE}>25$ pode ser utilizado da mesma forma que o índice EI30 proposto por WISCHMEIER \& SMITH (1958) e conclui que $O$ cálculo do índice KE>25 apresenta maior vantagem do que o índice EI30, visto que é menos trabalhoso.

MORAIS (1986), objetivando determinar o índice de erosividade que melhor se ajustasse a três diferentes locais do Rio Grande do Sul (Guaíba, Ijuí e Santa Maria), estudou correlações lineares simples entre características da chuva e respectivas perdas de solo. Os dados obtidos indicaram que cada local apresentou um índice de erosividade diferente que melhor se correlacionou com as perdas de solo, sendo que para Guaíba o índice que melhor se correlacionou com as perdas de solo foi o $\mathrm{KE}>10$ que é computado de forma semelhante ao $\mathrm{KE}>25(\mathrm{r}=0,78)$.

CARVALHO

correlacionando

características físicas das chuvas com perdas de solo de Mococa-SP, constatou que a energia cinética apresentou um coeficiente de correlação mais alto do que a quantidade de chuva ( $r=0,7306$ e $r=0,6617$ respectivamente), entretanto - autor constatou também não haver diferença significativa 
entre os coeficientes de correlação da energia cinética total e precipitação total.

CARVALHO (1987), correlacionando 29

características da chuva e perdas de solo, correspondentes aos dados de oito anos de chuva em Mococa-SP, consatatou que as características da chuva $\mathrm{KE}>10$ e $\mathrm{KE}>25$ apresentaram os seguintes coeficientes de correlação: $r=$ 0,7956 e 0,8008 . o autor constatou também não existir diferença estatística entre os coeficientes de correlação das seguintes características entre si: EI30 e KE > 10, EI30 e $K E>25$.

2.2.4. Produto da energia cinética total pelas intensidades máximas (EIn)

\begin{abstract}
WISCHMEIER \& SMITH (1958), pesquisando a relação entre diferentes características físicas da chuva e perdas de solo dos E.U.A, com o objetivo de estabelecer um Indice de erosividade que melhor estimasse a capacidade da chuva de provocar erosão, verificaram que a perda de solo, provocada pelas chuvas em áreas cultivadas apresentou uma elevada correlação com o produto entre duas características das chuvas: energia cinética total e intensidade máxima em 30 minutos, denominado como indice EI30. Estatisticamente o
\end{abstract}


índice EI30 foi capaz de explicar 72 a $97 \%$ as perdas de solo causado pelas chuvas.

De acordo com WISCHMEIER \& SMITH (1978), O produto da energia cinética da chuva por sua intensidade máxima em 30 minutos mede os efeitos do impacto das gotas e turbulência combinados com a capacidade de transporte da enxurrada.

WISCHMEIER (1959), relata que a definição exata de uma chuva individual erosiva foi de fundamental importância no cálculo da energia cinética do índice EI30. O autor constatou que as melhores correlações entre o índice EI30 e as perdas de solo foram obtidas quando chuvas separadas por um intervalo menor que seis horas foram consideradas como uma única chuva. Chuvas com menos de 12,7 $\mathrm{mm}$ e separadas de outra por mais de seis horas não foram incluidas no cálculo, com exceção das chuvas de 6,4 mm que ocorrecem num tempo de 15 minutos. Afirma o autor que o tempo mínimo e ótimo definido como o intervalo entre duas chuvas, é função da taxa de infiltração após o término da primeira chuva.

STOCKING \& ELWELL (1973), correlacionando diferentes características da chuva com perdas de solo de parcelas descobertas e parcelas cultivadas de dois solos de Rodésia, constataram que o indice de erosividade EI30 foi o que melhor estimou as perdas de solo provocadas pelas chuvas. 
BISCAIA et alii (1981), correlacionando o Índice EI30 com dados de perdas de solo das regiões de Londrina (Latossolo Rôxo distrófico) e Ponta Grossa (Latossolo Vermelho álico) no estado do Paraná, obtiveram os seguintes coeficiente de correlação: $r=0,72$ e 0,77 para Londrina e Ponta Grossa respectivamente.

MORAIS (1986), estudou correlações lineares simples entre características físicas da chuva e perdas de solo de três diferentes locais do Rio Grande do Sul (Guaíba, Ijuí e Santa Maria). Os dados obtidos possibilitaram as seguintes conclusões: a) cada local apresentou um índice de erosividade diferente que melhor se correlacionou com as perdas de solo. b) para Ijuí e Santa Maria os índices que melhor se correlacionaram com as perdas de solo foram os Indices $\operatorname{EI} 10$ e EI5 $(r=0,761$ e 0,783$)$ b) para todos os locais estudados, $\circ$ indice EI25 $(r=0,652)$ foi $\circ$ que apresentou a melhor correlação c) o índice EI25 não deve ser indicado como mais adequado do que 0 índice EI30 ( $\mathrm{F}=$ 0,647), devido a ausência de diferênça estatística significativa entre os dois coeficientes de correlação; e) o Índice de erosividade EI30 pode ser considerado como adequado para estimar o potencial erosivo das chuvas para os três locais estudados até que novas informações estejam disponíveis.

FOSTER et alii (1982), correlacionaram 21 características da chuva com perdas de solo para 10 locais do 
E.U.A e 1 local do Brasil. Os autores obtiveram dados que possibilitaram as seguintes conclusões: a) a combinação da quantidade de chuva, quantidade de enxurrada e a intensidade da chuva em um único indice de erosividade (QxExI) foi melhor estimador das perdas de solo do que o indice EI30, entretanto os autores ressaltam, que o indice de erosividade EI30 é um bom estimador das perdas de solo e que os índices de erosividade que incluiram quantidade de chuva, intensidade e enxurrada, apesar de apresentarem uma melhor correlação não apresentaram uma melhora na predição de perdas de solo que pudesse ser considerada significativa. Os autores esclarecem entretanto que as maiores vantagens de um termo que combine a quantidade de chuva e a enxurrada num único índice de erosividade são as seguintes: 1이 redução da superestimação de perda de solo quando a enxurrada é insignificante e a quantidade de chuva e a intensidade são grandes. 20) redução da subestimação das perdas de solo quando a enxurrada é grande em relação a chuva e a intensidade.

CARVALHO (1987), estudou correlações entre 29 caracteristicas da chuva e perdas de solo, correspondentes aos dados de oito anos de chuva em Mococa-sp. Através dos dados obtidos o autor obteve as seguintes conclusões: a) as características da chuva do tipo EIn apresentaram os seguintes coeficientes de correlação: $r=0,8008$ (EI25) a 0,7706 (EI5), b) não existe diferença significativa entre os 
coeficientes de correlação das características EI25 e EI5, e por conseguinte não existe diferença entre os coeficientes de correlação das seguintes características entre si: EI30 e KE $>25, \operatorname{EI} 25$ e EI30 e EI25 E KE>25. C) existe diferença siginificativa ao nível de $5 \%$ de probabilidade entre os coeficientes de correlação da energia cinética total e o coeficiente de correlação do índice EI30 d) existe diferença significativa ao nivel de $5 \%$ de probabilidade entre os índices EI30, KE>10 e $\mathrm{KE}>25$.

LOMBARDI NETO (1977), tomando como base o registro de chuvas Campinas-SP, correspondente a um período de 22 anos, calculou o índice de erosividade EI30, obtendo para o Índice de erosividade médio anual um valor de 6769 MJ.mm/ha.h.ano. A análise estatística indicou um desvio padrão de 2423 MJ.mm/ha.h.ano e um coeficiente de variação de $35,8 \%$. O autor verificou que apenas $74 \%$ da precipitação pluviométrica média anual foram incluidas no cálculo do Índice de erosividade EI30 e concluiu que 90,78 do indice de erosividade ocorreu durante os meses de outubro a março, sendo que para este período a quantidade anual de chuva correspondente é de $80.1 \%$.

$$
\text { DEDECEK (1978), utilizando dados }
$$

correspondente a oito anos de registro de chuva de BrasíliaDf, calculou $\circ$ indice de erosividade EI30 médio anual, obtendo um valor de $8319 \mathrm{MJ} . \mathrm{mm} / \mathrm{ha} \cdot \mathrm{h} . \mathrm{ano}$. Constatou que os 
meses com maior percentual erosivo corresponderam ao período que vai de outubro a janeiro.

PEREIRA (1983), calculou o valor médio anual

para 0 indice EI30 a partir de vinte anos de registro pluviográfico em Piracicaba -SP, obtendo um valor de 5730 $\mathrm{MJ} \cdot \mathrm{mm} / \mathrm{ha} \cdot \mathrm{h} \cdot$ ano

CAMPOS FILHO et alii (1984), utilizando dez anos de dados pluviográficos de Gloria de Goitá-PE, obtiveram para o indice de erosividade EI30 médio anual um valor de $3484 \mathrm{MJ} \cdot \mathrm{mm} / \mathrm{ha} \cdot \mathrm{h}$. ano.

Cogo et alii (1978), calcularam o Indice de erosividade EI30 para alguns municipios do Rio Grande do Sul, obtendo valores médios anuais de 6275 MJ.mm/ha.h.ano em Guaíba, 8606 MJ.mm/ha.h.ano em Ijui e 7695 MJ.mm/ha.h.ano em Passo Fundo, para 9,13 e 12 anos de registro pluviográficos respectivamnte. Estes autores constataram que as maiores concentrações de percentagem acumulada do índice de erosividade médio anual ocorreram nos meses de dezembro, fevereiro e junho para Guaíba, dezembro e fevereiro para Ijuí e dezembro, fevereiro e março para Passo Fundo.

LAGO (1984), utilizando vinte e cinco anos de dados pluviográficos de Pelotas-RS, calculou $\circ$ índice de erosividade médio anual, obtendo um valor de 3924 MJ . mm/ha.h.ano. 
CHAVES \& DINIZ (1981), utilizando dados de registro pluviográfico da divisão de hidrometeorologia da SUDENE, calcularam o Índice de erosividade EI30 médio anual para dez localidades do estado da Paraiba. Os autores agruparam as dez localidades em três grupos com características climáticas relativamente homogêneas a saber: a) Areias e Guarabira com clima do tipo As quente úmido com chuvas de outono-inverno, b) Barra de Sta Rosa, São Vicente e Taperoá com clima semi-arido quente e c) Teixeira, Itaporanga, Bonito de Sta Fé, Antenor e Catolé do Rocha com clima quente e umido e com chuvas de verão-outono. A partir da análise dos dados de chuvas dessas localidades os autores chegaram as seguintes conclusões: a) Guariba apresenta uma precipitação média anual de $1054 \mathrm{~mm}$, com um valor do índice de erosividade médio anual de 4159 MJ.mm/ha.h.ano, enquanto que Areias é a estação meteorológica de mais alto valor pluviométrico com $1506 \mathrm{~mm}$, entretanto com um valor do Índice de erosividade médio anual de $3855 \mathrm{MJ} . \mathrm{mm} / \mathrm{ha} \cdot \mathrm{h}$. ano, considerado um dos mais baixos do estado. Os autores observaram ainda que houve um aumento gradativo da erosividade a partir do mês de dezembro, que decresce a após o mês de abril em Guarabira, e março em Areias; b) Barra de Sta Rosa, são vicente do Seridó e Taperoá é o grupo que apresentou os mais baixos valores do índice de erosividade, $1462 \mathrm{MJ} . \mathrm{mm} / \mathrm{ha} \cdot \mathrm{h} . \mathrm{ano}, 2776 \mathrm{MJ} \cdot \mathrm{mm} / \mathrm{ha} \cdot \mathrm{h}$. ano e 3199 
MJ.mm/ha.h.ano respectivamente. Os baixos Indices de erosividade são explicados pelo fato de ser esta a região mais seca do estado com precipitação de $363 \mathrm{~mm}, 411 \mathrm{~mm}$ e 443 $\mathrm{mm}$ respecivamente. Nos meses de fevereiro, março, abril e maio ocorreram entre 50 a $70 \%$ do indice de erosividade; c) Teixeira, Itaporanga, Bonito, Antendor e Catolé apresentaram valores intermediários de precipitação $(744 \mathrm{~mm}, 690 \mathrm{~mm}, 989$ $\mathrm{mm}, 673 \mathrm{~mm}$ e $956 \mathrm{~mm}$ respectivamente), e entretanto os mais altos valores do índice de erosividade médio anual: 7819 MJ.mm/ha.h.ano, 4149 MJ.mm/ha.h.ano, 7535 MJ.mm/ha.h.ano, 4974 MJ.mm/ha.h.ano e 6838 MJ.mm/ha.h.ano respectivamente). Fevereiro, março e abril são normalmente os meses onde se concentram as chuvas mais erosivas nestas localidades.

WISCHMEIER (1959), estudando a distribuição da probabilidade de ocorrência do índice de erosividade anual da chuva para 4 locais dos E.U.A, verificou que a distribuição da probabilidade do índice de erosividade EI30 anual seguiu o padrão log-normal. O autor ressalta que esse tipo de distribuição é característico de muitos dados hidrológicos.

LOMBARDI NETO (1977), estudou a distribuição da probabilidade de ocorrência do índice de erosividade EI30 para Campinas-SP e constatou que a distribuição da probabilidade de ocorrência do índice de erosividade EI30 anual seguiu o padrão log-normal. 


\subsubsection{Produto da precipitação pluviométrica total pelas intensidades máximas (PIn)}

LAL (1976), pesquisando nas condições da Nigéria a correlação entre diferentes características da chuva (EI30, KE>25 e PIn 7,5) e perdas de solo em parcelas de solo descoberta, constatou uma boa correlação entre os Indices $\operatorname{EI} 30, \mathrm{KE}>25$ e $\operatorname{PIn} 7,5$ com as perdas de solo. Entretanto o autor ressalta que para regiões tropicais o Indice AIm apresenta algumas vantagens sobre o EI30 e $0 \mathrm{KE}>25$ tais como: 1의 inclui a intensidade máxima, uma característica importante nas chuvas tropicais, 20) leva em consideração a chuva total, visto que uma chuva muito intensa, mas de curta duração pode resultar numa pequena quantidade de chuva, podendo ser não erosiva. Segundo o autor - Índice de erosividade $\operatorname{PIn} 7,5$ pode ser calculado pela seguinte equação:

$$
\operatorname{PIn}=\{\stackrel{12}{\Sigma}(\stackrel{\mathrm{n}}{\Sigma} \operatorname{PIn})\}
$$

onde:

$$
\begin{aligned}
\text { PIn } & =\text { índice de erosividade médio anual } \mathrm{cm} / \mathrm{h} ; \\
\mathrm{P} & =\text { quantidade de uma chuva individual em } \mathrm{cm} ; \\
\mathrm{In} & =\text { intensidade máxima em } 7,5 \mathrm{~min} \mathrm{em} \mathrm{cm} / \mathrm{h} ; \\
\mathrm{n} & =\text { número de dias de chuva em um mês. }
\end{aligned}
$$


FOSTER et alii (1982), correlacionando 21 características da chuva com perdas de solo para 10 locais do E.U.A e 1 local do Brasil, constataram que, quando a quantidade de chuva foi multiplicada pela intensidade máxima em 30 minutos ( $P \quad x \quad I 30)$ houve uma melhora, mas não significativa do coeficiente de correlação $(0,229$ a 0,778$)$. MORAIS (1986), correlacionando os índices do tipo EIm e AIm com as respectivas perdas de solo registradas em Ijuí, R.G.S, constatou que os índices EI10 AI10 ( $\mathrm{r}=$ 0,758 e 0,761 respectivamente, foram os que melhor se correlacionaram em valores absolutos com as perdas de solo. MEDINA \& OLIVEIRA JUNIOR (1987), correlacionando vários índices de erosividade com perdas de solo correspondente ao período de 1983 a 1985 para as condições de Manaus-AM, constataram que os índices de erosividade que melhor se correlacionaram com as perdas de solo foram 0 PIn7,5 e o EI7,5 ( $\mathrm{E}=0,73$ e 0,70 respectivamente).

2.3. Estimativa do índice de erosividade a partir de dados pluviométricos.

Quando em determinada região são excassos dados de chuva obtidos a partir de pluviógrafos, o cálculo do Indice de erosividade pode ser obtido através de correlações e equações de regressão entre índices de erosividade e dados 
pluviométricos. Outro aspecto que se tem levado em consideração para se estimar o Indice de erosividade a partir de dados pluviométricos é o fato de que o cálculo do índice de erosividade, mormente daqueles que envolvem o cálculo da energia cinética é trabalhoso e demorado. CARVALHO (1987).

Furnier *, citado por LOW (1966), encontrou uma alta correlação entre erosão total e um coeficiente de distribuição de chuva dado pela seguinte expressão:

$$
R=\frac{p^{2}}{p}
$$

onde:

$$
\begin{aligned}
& \mathrm{p}=\text { é o total de chuva do mês mais úmido, } \\
& \mathrm{P}=\text { é a chuva total anual. } \\
& \text { LOMBARDI NETO \& MOLDENHAUER }
\end{aligned}
$$

constataram um alto coeficiente de correlação entre o indice de erosividade médio mensal e o coeficiente chuva modificado de Furnier (1960), correspondente a vinte e dois anos de dados de chuva de Campinas-SP. A equação obtida é a seguinte:

$$
E I=6,872\left(P^{2} / P\right)^{0,850}
$$

onde:

* FURnIER, F. Climate et Erosion. Press Universituires de France, Paris, 1960. 201p. 
$\mathrm{EI}=$ é a média mensal do Índice de erosão em tm. mm/ha.h

$$
\begin{aligned}
& \mathrm{p}=\text { é a precipitação média mensal em mm, } \\
& \mathrm{p}=\text { é a precipitação média anual em } \mathrm{mm} .
\end{aligned}
$$

CARVALHO (1987), correlacionando o índice de erosividade EI30 médio mensal de Mococa-SP e o coeficiente de chuva proposto por LOMBARDI NETO (1977), obteve um coeficiente de correlação altamente significativo $(r=0,991)$. A equação de regressão obtida é a seguinte:

$$
\operatorname{EI} 30=111,173\left(\mathrm{p}^{2} / \mathrm{P}\right)^{0,691}
$$

onde:

$$
\text { EI30 = é o indice de erosividade médio mensal }
$$

em $M J \cdot m m / h a \cdot h$,

$$
\begin{aligned}
& \mathrm{p}=\text { é a precipitação média mensal em mm, } \\
& \mathrm{P}=\text { é a precipitação média anual em } \mathrm{mm} \text {. }
\end{aligned}
$$




\section{MATERTAL E MÉtOdOS}

\subsection{Material Utilizado}

\subsubsection{Localização da área experimental}

Os dados utilizados para a concretização deste trabalho foram obtidos na Estação Experimental de Caruaru-PE, através do Programa de Conservação do solo de Pernambuco. A Estação Experimental de Caruaru-PE, vinculada a Empresa de Pesquisa Agropecuária de Pernambuco (IPA). está - localizada a 38000 '00' a oeste de Greenwich e Latitude de 8000r00'r sul e a uma altitude de $537 \mathrm{~m}$ acima do nível do mar.

\subsubsection{Descrição do clima e do solo}

\subsubsection{Clima}

De acordo com a classificação de Koeppen a região de Caruaru-PE está enquadrada no tipo climático As` ou seja Megatérmico seco subúmido. A precipitação 
pluviométrica média anual é de $723,8 \mathrm{~mm}$, a temperatura média anual é de $24,3 \mathrm{C}^{\circ}$ e a umidade relativa média anual é de $59 \%$.

Este tipo de clima apresenta um regime pluviométrico bastante irregular ao longo do ano e de ano para ano. O periodo chuvoso concentra-se de março a julho, onde ocorrem 67,33 \& da precipitação anual. O período mais seco compreende os meses de setembro a dezembro. Ao longo do ano o balanço hídrico é sempre negativo, ou seja não apresenta excedentes de umidade. As chuvas decorrem dos efeitos da frente polar antártica e da frente de convergência intertropical.

\section{$3.1 \cdot 2 \cdot 2$. Solo}

o solo onde estão localizados os canteiros coletores de enxurrada está classificado como: Regossolo Eutrófico A moderado, textura arenosa fase caatinga hiperxerófila, originado da decomposição de rochas gnaisses, Pré-cambianas (cd) gnaiss.

\subsubsection{Pluviógrafo e pluviômetros}

Para o registro das chuvas correspondentes ao período de 1970 a 1989 foi utilizado um pluviógrafo do tipo IH, que funciona através do acionamento de um mecanismo de relógio com capacidade de registrar chuvas no decorrer de um período de vinte e quatro horas. 
Nos pluviogramas as chuvas são registradas na ordenada de $0,1 \mathrm{~mm}$ em $0,1 \mathrm{~mm}$ até atingir um total de $10 \mathrm{~mm}$. enquanto que o tempo é registrado na abcissa de dez em dez minutos durante um período de $24 \mathrm{hs}$. (Figura 1).

Os dados pluviométricos foram obtidos a partir de pluviômetros do tipo ville DeParis, onde o registro de altura de chuva é feita para cada período de $24 \mathrm{hs}$.

\subsubsection{Ficha para a leitura dos pluviogramas e} cálculo da erosividade das chuvas

Para a análise dos registros pluviográficos e cálculo das características das chuvas foi utilizada uma ficha composta de oito colunas. (Figura 2 ).

\subsubsection{Descrição da parcela experimental e dos coletores de solo e enxurrada.}

Os dados de perdas de solo que foram utilizados nos estudos de correlação com as características da chuva, foram coletados de uma parcela experimental com área de 100 metros quadrados $(25 \mathrm{~m}$ de comprimento e 4 metros de largura) e declividade de $12 \%$.

A jusante da parcela experimental está localizado o sistema coletor de solo e enxurrada, que é constituído por dois tanques de alvenaria construídos em 


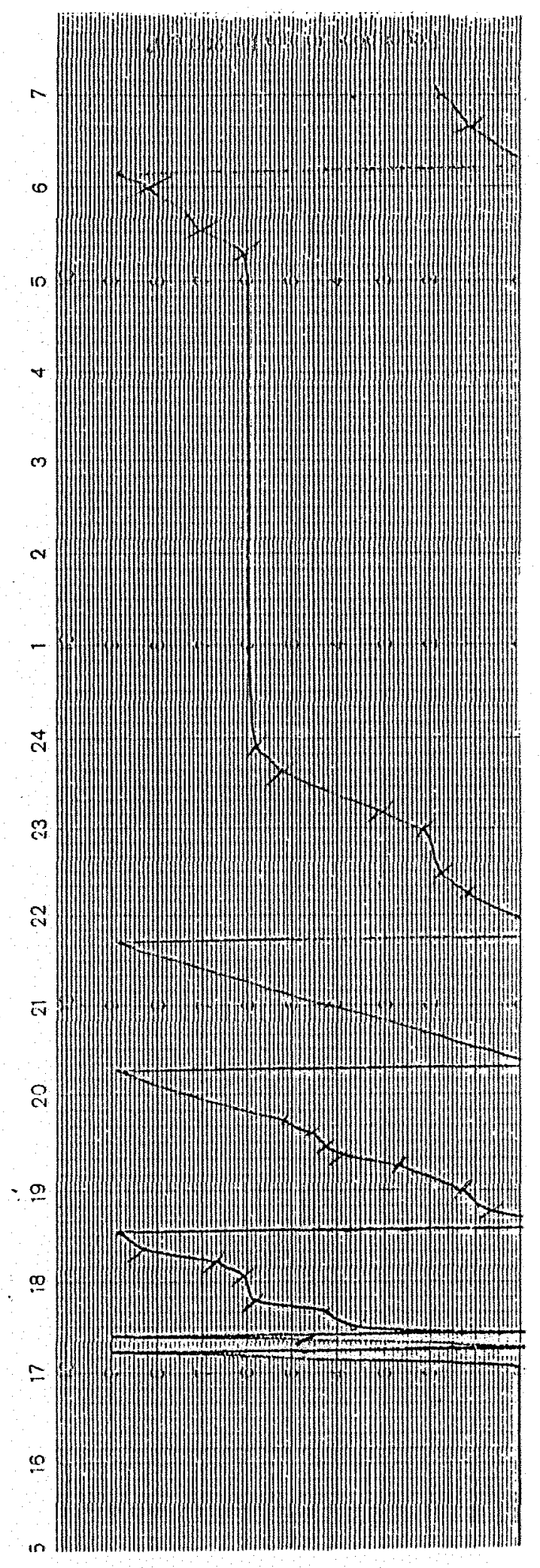


séries e interligados com calhas divisoras de nove janelas do tipo Geib.

\subsubsection{Programas para microcomputadores}

Para os cálculos estatísticos envolvendo

correlações, equações de regressão, analise de variância e teste de signficância foi utilizado o programa SAEG - Sistema de Análise Estatística e Genética desenvolvido pela Universidade Federal de Viçosa-MG

Para a elaboração dos gráficos foi utilizado o programa MSCHART. 2.0.

\subsection{MÉTODOS UTILIZADOS}

3.2.1. Critérios utilizados para separar chuvas erosivas

Os critérios adotados para separar as chuvas erosivas baseou-se naqueles propostos por WISCHMEIER (1959) e modificados por CABEDA (1976). Os critérios utilizados são os seguintes:

\footnotetext{
a) considerou-se como erosivas,

precipitações que apresentarem altura igual ou superior a $10.0 \mathrm{~mm}$,
} 


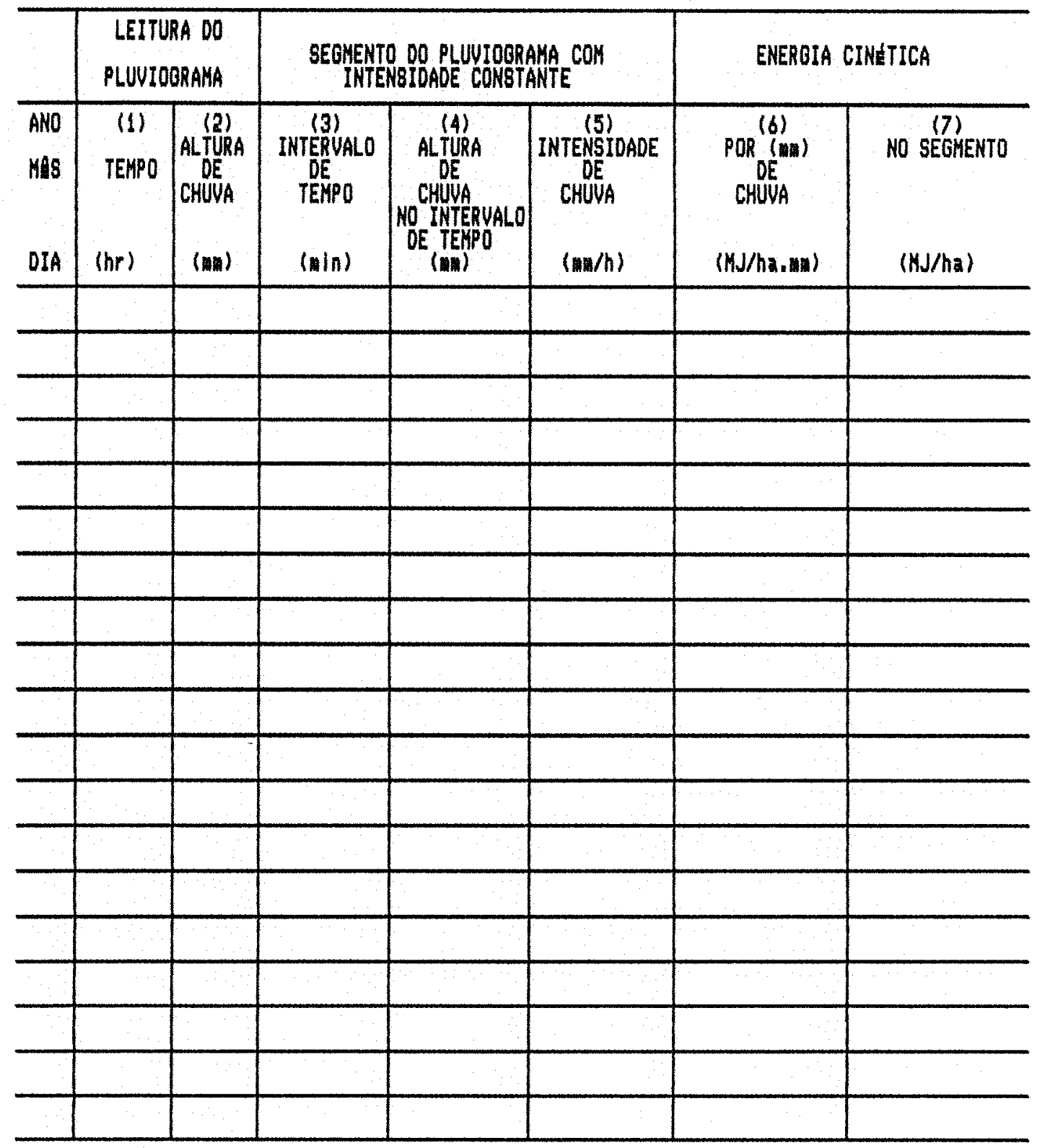

Figura 2. Ficha de leitura dos pluviograna e cálculo da erosividade das chuvas 
b) considerou-se como erosivas as precipitacões que apresentarem altura menor do que $10,0 \mathrm{~mm}$, se tiverem em 15 minutos uma precipitação igual ou superior a $6 \mathrm{~mm}$,

Com base nestes critérios foram analisados dados de chuvas correspondente ao período de 1970 a 1989. Tendo-se constatado que os dados correspondentes aos anos de 1977 e 1983, estavam incompletos, levando-se em consideração somente os dados correspondentes a 18 anos.

\subsubsection{Determinação dos segmentos de intensidade uniforme das chuvas erosivas}

Atendido os critérios acima estabelecidos, procedeu-se a análise dos registros pluviográficos, de acordo com as seguintes recomendações proposta por CABEDA (1976):

a) separou-se com a marca de um lápis no pluviograma as seções da curva com aclive uniforme ou seja segmentos de chuva com intensidade constante,

b) leu-se e anotou-se na ficha da figura 2, a hora inicial e final e a quantidade de chuva de cada segmento do gráfico com intensidade constante, nas colunas 1 e 2 , respectivamente.

c) anotou-se nas colunas 3 e 4, respectivamente $\circ$ tempo de duração e a quantidade de chuvas dos segmentos de intensidade constante. 


\subsubsection{Determinação das características das chuvas erosivas}

Após a cotação dos pluviogramas das chuvas individuais erosivas (figura 1), foram realizados os cálculos para a obtenção dos valores correspondentes as características a serem testadas como índices de erosividade das chuvas erosivas.

As caracteristicas das chuvas individuais erosivas, que foram consideradas como variáveis independentes são as seguintes: a) precipitação pluviométrica total (P) em $\mathrm{mm}$, b) intensidades máximas ocorridas nos tempos de 5, 10, 15, 30 e 60 minutos (In) em $\mathrm{mm} / \mathrm{h}, \mathrm{c})$ produtos da energia cinética total pelas intensidades máximas de chuva em intervalos crescentes de tempo (EIn), ou seja EI5, EI10, EI15,EI30 e EI60 em Mj.mm/ha.h, d) produtos da quantidade total de chuva pelas intensidades máximas das chuvas em interva-los crescentes de tempo (PIn), ou seja PI5, PI10, PI15, PI30 e PI60 em $\mathrm{mm}^{2} / \mathrm{h}$, e) somatório da energia cinética de intensidades maiores do que $10 \mathrm{~mm} / \mathrm{h}(\mathrm{KE}>10) \mathrm{em}$ MJ/ha, f) somatório da energia cinética de intensidades maiores do que $25 \mathrm{~mm} / \mathrm{h}(\mathrm{KE}>25)$ em $\mathrm{MJ} / \mathrm{ha}$ e g) energia cinética total em $\mathrm{MJ} / \mathrm{ha}$ 
Os valores correspondente a quantidade diárias total de chuva erosiva foram obtidos através da do somatório dos valores da coluna 4 (Figura 1 ).

\section{$3 \cdot 2 \cdot 3 \cdot 2$. Intensidades máximas (In)}

As intensidades máximas (In) para os tempos de $5,10,15,30$ e 60 minutos respectivamente, foram calculadas de acordo com as seguintes etapas:

a) determinou-se no pluviograma a parte da curva onde a chuva apresentou a maior inclinação,

b) identificou-se na parte de maior inclinação da curva onde ocorreu a maior altura de chuva dentro dos tempos de $5,10,15,30$ e $60 \mathrm{~min}$.

c) Multiplou-se por $12,6,4,2$ e 1 os tempos acima mencionados para obter-se as respectivas intensidades máximas em $\mathrm{mm} / \mathrm{h}$.

Para chuvas com duração menor do que 5,10 , 15,30 e 60 minutos, as intensidades máximas foram calculadas como se as mesmas tivessem $5,10,15,30$ e 60 minutos respectivamente.

3.2.3.3. Energia cinética total (ECT)

- método utilizado para o cálculo da energia cinética total de chuvas individuais erosivas, seguiu o 
procedimento de WISCHMEIER \& SMITH (1958), modificado por CABEDA (1976), como a seguir é mencionado:

a) calculou-se a energia cinética em $\mathrm{MJ} / \mathrm{ha} \cdot \mathrm{mm}$ (coluna 6), referentes a intensidade $(\mathrm{mm} / \mathrm{h})$ de cada segmento de intensidade constante, através da equação (7), expressa no Sistema Internacional de Unidades por FOSTER et alii (1981).

$$
E=0,119+0,0873 \log I
$$

onde:

$$
\begin{aligned}
& \mathrm{E}=\text { energia cinética em } \mathrm{MJ} / \mathrm{ha} \cdot \mathrm{mm} \\
& \mathrm{I}=\text { intensidade de cada segmento com }
\end{aligned}
$$
intensidade constante $(\mathrm{mm} / \mathrm{h})$.

Para valores da energia cinética correspondente a intensidades iguais ou superiores a $76 \mathrm{~mm} / \mathrm{h}$ a energia cinética passa a ter um valor máximo de 0,2832 MJ/ha segundo as recomendações de FOSTER et alii (1981)

b) multiplicou-se a energia cinética em MJ/ha.mm de cada segmento com intensidade constante, pela quantidade de chuva (coluna 4), dos respectivos segmentos para se obter a energia cinética de cada incremento de chuva em MJ/ha (coluna 7),

c) somou-se os valores da energia cinética em MJ/ha de todos os segmentos de chuva com intensidade constante (coluna 7), para obter-se a energia cinética total da chuva. 
3.2.3.4. Produto da energia cinética total pelas intensidades máximas (EIn)

As características da chuva do tipo EIn, foram calculadas de acordo com a metodologia proposta por WISCHMEIER (1959), e adaptada por CABEDA (1976) e que podem ser expressas matematicamente pela seguinte equação:

$$
\mathrm{EIn}=\mathrm{Ec} \cdot \mathrm{In} \cdot 10-3
$$

onde:

$$
\text { EIn = produto da energia cinética total pelas }
$$
intensidades máximas em Mj.mm/ha.h,

$$
\text { In }=\text { intensidades máximas em } 5,10,15,30 \mathrm{e}
$$

60 minutos em $\mathrm{mm} / \mathrm{h}$,

$$
\mathrm{EC}=\text { energia cinética total em } \mathrm{Mj} / \mathrm{ha} \text {. }
$$

3.2.3.5 Produto da precipitação pluviométrica total de chuva pelas intensidades máximas (PIn)

As caracerísticas da chuva do tipo (PIn) foram calculados de acordo com a metodologia proposta por LAI (1976) e modificada por MEDINA (1987). Efetuou-se o produto da quantidade total da precipitação pluviométrica para cada chuva individual erosiva em mm pelas intensidades máximas em $5,10,15,30$ e 60 minutos respectivamente. 
Com o objetivo de obter-se grandezas semelhantes as do índices de erosividade EIn, $\circ$ que facilitaria a sua aplicação prática, o Índice de erosividade PIn foi dividido por 100 como proposto por MEDINA, 1987.

3.2.3.6. Energia cinética de segmentos de chuva com intensidade constante igual ou maior do que 10 e $25 \mathrm{~mm} / \mathrm{h}$ ( $\mathrm{KE}>10$ e $\mathrm{KE}>25$ respectivamente)

O cálculo do Índice de erosividade $\mathrm{kE}>\mathrm{n}$ foi determinado tomando como base a metodologia desenvolvida por HUDSON (1981).

0 Indice de erosividade $\mathrm{KE}>25$ de cada chuva inidividual erosiva foi calculado a partir da soma dos valores da energia cinética, concernentes a segmentos de intensidade constante igual ou superior que $25 \mathrm{~mm} / \mathrm{h}$.

0 Indice de erosividade $K E>10$ foi calculado de forma semelhante ao índice de erosividade KE $>25$.

\subsubsection{Coleta do material erodido}

As coletas dos dados de perdas de solo e enxurrada da parcela descoberta corresponderam ao período de $1975 / 76 / 78 / 79 / 80$. 
A jusante da parcela descoberta foram instaladas calhas coletoras para conduzirem a enxurrada para os tanques coletores. No interior do primeiro tanque, 0 sedimento mais pesado é sedimentado e quando a enxurrada enche $\circ$ primeiro tanque o excedente é fracionado através de divisor tipo Geib onde apenas $1 / 9$ do material é armazenado no segundo tanque.

Após cada chuva, o material foi coletado nos tanques, medido e amostrado de acordo com as recomendações de BERTONI (1949) e MARQUES (1951).

Como a parcela descoberta possui uma declividade de $12 \%$, foi feita a correção para a declividade de $9 \%$, no sentido de atender as especificações da parcela padrão. A correção das perdas de solo para o declive da parcela padrão foi feita utilizando-se a equação abaixo, proposta por BERTONI (1949):

$$
A=0,018 \cdot S 1,18 \cdot L^{1,63,}
$$

onde:

$\mathrm{A}=$ é a perda de solo em $\mathrm{Kg}$ por unidade de largura,

$\mathbf{S}=$ é $\circ$ grau de declive em porcentagem,

$L=$ é o comprimento de rampa em metros.

A transformação direta das perdas de solo para as condições da parcela padrão foi feita utilizando-se a equação proposta por BERTONI (1959) que é a seguinte: 


$$
\mathrm{A} 1=0,709 \cdot \mathrm{A} 2,
$$

onde:

$A 1$ = é a perda de solo em $t / h a$ para $\circ$ declive de 9,08 de declividade, concernente a parcela padrão,

$A 2$ = é a perda de solo em $t /$ ha para $\circ$ declive de $12 \%$ da parcela descoberta.

Deve-se ressaltar, que a correção concernente ao comprimento de rampa da parcela para a parcela padrão $(22,14 \mathrm{~m})$, não foi efetuada, atendendo as especificações de BERTONI (1949) e MARQUES (1951), que estabeleceram para a parcela padrão o comprimento de $25 \mathrm{~m}$.

\subsubsection{Manejo da parcela experimental}

- manejo da parcela descoberta seguiu as recomendações de WISCHMEIER \& SMITH (1978), ou seja, a parcela foi mantida sem cobertura vegetal através do preparo e cultivo do solo com enxada no sentido do declive.

3.2.6. Correlaçōes entre características físicas das chuvas erosivas e perdas de solo.

As correlações entre as características fisicas da chuva e perdas de solo foram obtidas através do sistema de análise estatística e genética (SAEG), da 
Universidade Federal de Viçosa. As caracteristicas das chuvas foram consideradas para fins dos estudos de correlações como sendo as variáveis independentes enquanto que as perdas de solo (t/ha) foram consideradas como sendo a variavel dependente.

Foram calculadas as equações de regressão linear simples e por conseguintes o coeficiente linear (a), - coeficiente de regressão (b) e o coeficiente de correlação (r), entre as caracaterísticas das chuvas $e$ as perdas de solo.

A verificação da homogeneidade entre os coeficientes de correlação foi realizada através do teste de homogeneidade proposto por GRAYBILL (1961), onde os coeficientes de correlação foram testatos dois a dois.

3.2.7. Distribuição do índice de erosividade EI30 (Fator "R")

A caracterização detalhada desse índice constou das seguintes etapas: a) determinação do índice de erosividade ET30 mensal, b) determinação do indice de erosividade EI30 médio mensal, c) determinação do índice de erosividade anual, d)determinação do Índice de erosividade médìo anual e e) determinação da probabilidade de ocorrência e do período de retorno do valor do EI30 médio anual. 
3.2.7.1. Determinação do índice de erosividade mensal

o Indice de erosividade EI30 mensal de cada mês dos anos compreendidos no período estudado, foram calculados a partir da soma dos indices EI30 da chuvas indiviuais erosivas que ocorreram em cada mês.

\subsubsection{Determinação do indice de erosividade médio mensal}

O Indice de erosividade EI30 médio mensal para um determinado mês foi calculado através da média aritmética dos dezoitos valores do índice de erosividade EI30 mensal, ocorridos naquele mês no período de 1970 a 1989 .

3.2.7.3. Determinação do Índice de exosividade estacional

0 Índice de erosividade EI30 para uma determinada estação do ano foi calculado pela soma dos valores do índice de erosividade EI30 médio mensal, correspondentes aos meses de cada estação.

3.2.7.4. Determinação do indice de erosividade anual 
O valor do Índice de erosividade EI30 anual para um determinado ano foi calculado através do somatório dos valores do índice de erosividade mensal, ocorridos durante cada ano.

3.2.7.5. Determinação do indice de erosividade médio anual (Fator "R" da equação universal de perdas de solo)

o valor do índice de erosividade EI30 médio anual ou fator "R" da equação universal de perdas de solo, correspondente ao período de 1970 a 1989 foi calculado através da média aritmética dos 18 valores dos indices de erosividade EI30 anual.

\subsubsection{Determinação da curva de distribuição do indice de erosividade EI30}

A determinação da curva de distribuição temporal do indice de erosividade EI30 foi realizada a partir da plotação das percentagens acumuladas correspondentes aos valores dos indices de erosividade médio mensal. Os pontos plotados foram unidos, resultando na curva de distribuição do Índice de erosividade. 
3.2.8. Probabilidade de ocorrência e período de retorno dos valores do índice de erosividade anual

A determinação da probabilidade de ocorrência dos valores do índice de erosividade anual para vinte anos de dados de chuva de Caruaru-PE, foi realizada tomando como base na teoria do valor extremo e a lei da probabilidade logarítimica como apresentada por SCHWAB et alii (1981).

o cálculo da distribuição da probabilidade de ocorrência foi realizada a paxtir da seguinte equação apresentada por SOUZA PINTO et alii (1976):

$$
\operatorname{Pr}=\frac{100}{T}
$$

onde:

$$
\operatorname{Pr}=\text { é a probabilidade de ocorrência do evento }
$$

em percentagem,

$$
\mathrm{T}=\text { é o período de retorno. }
$$

A determinação da distribuição da probabilidade de ocorrência exige uma amostra contínua dos eventos hidrológicos WISCHMEIER (1959). Como não existiam registro pluviográfico dos anos de 1977 e 1983, os mesmos tiveram que ser incluídos através da média ponderada entre os anos adjacentes cronologicamente, de acordo com a recomendação apresentada por CARVALHO (1987). 
De acordo com SOUZA PINTO et alii (1976), determinação do período de retorno de um determinado evento hidrológico pode ser feita através da seguinte equação:

$$
\mathrm{T}=\frac{\mathrm{N}+1}{\mathrm{~m}}
$$

onde:

anos,

$$
\mathrm{T} \text { = é o período de retorno ou frequência em }
$$$$
\mathbf{N}=\text { é } \circ \text { número de anos dos eventos }
$$

hidrológicos analisados,

$$
\mathrm{m}=\text { é o número do evento hidrológico em ordem }
$$

decrescente.

Para o cálculo do período de retorno de um determinado valor do indice de erosividade anual, os respectivos valores do índice de erosividade anual foram colocados em ordem decrescemte, sendo determinado a seguir para cada valor do indice de erosividade anual, o respectivo período de retorno.

A obtenção do valor teórico de um evento hidrológico qualquer e correspondente a um determinado periodo de retorno, pode ser estimado a partir da seguinte equação apresentada por scHWAB et alii (1981):

$$
x_{C}=x(1+c \cdot k) \text {, }
$$


onde:

$$
\mathrm{xc}=\text { é o valor teórico de um evento }
$$

hidrológico para um determinado período de retorno,

$$
\mathrm{x}=\text { é a média aritmética dos eventos }
$$

hidrológicos,

$\mathrm{CV}=$ é o coeficiente de variação dos eventos,

$k=$ é o fator de frequencia do evento para o período de retorno desejado.

Os valores correspondentes ao fator de frequências (k), foram obtidos a partir da tabela apresentada por SOUZA PINTO et alii (1976), onde o fator de frequência foi calculado teoricamente para diversos períodos de recorrência em função do coeficiente de assimetria que é obtido através da seguinte equação:

$$
\mathrm{Csa}=\operatorname{Cs}(1+\mathrm{Fs}) \text {, }
$$

onde:

$$
\begin{aligned}
& \text { Csa }=\text { coeficiente de assimetria ajustado } \\
& \text { Cs }=\text { coeficiente de assimetria avaliado } \\
& \text { Fs }=\text { fator de correção para o coeficiente de }
\end{aligned}
$$

assimetria.

Com base na equação (14) foram calculados os valores teóricos do indice de erosividade EI30 anual correspondente aos seguintes periodos de retorno: $2,5,20$ e 100 anos.

A determinação do número mínimo de anos de uma série hidrológica que pode ser considerada como aceitavel, 
foi obtida através da seguinte equação mencionada por SCHWAB et alii (1981):

$$
Y=(4.30 \cdot t \cdot \log x)^{2}+6
$$

onde:

$\mathrm{Y}=$ é o número mínimo de anos considerados como aceitável, correspondente a uma determinada série hidrológica,

$t=$ é o valor estatístico de student ao nível de $10 \%$ de significância com $(Y-6)$ graus de liberdade, $\mathrm{x}=$ é a relação entre o evento com período de retorno de 100 anos e o evento com período de retorno de 2 anos.

3.2.9. Estimativa do indice de erosividade médio mensal a partir de correlações com dados pluviométricos

Para cada mês do ano foi calculado o coeficiente de chuva, utilizando-se os valores pluviométricos médios mensais, concernente ao período de 1970 a 1989 . O coeficiente de chuva utilizado nos cálculos de correlação foi aquele proposto por LOMBARDI NETO (1977), cuja equação é abaixo mencionada: 


$$
\mathrm{Rc}=\frac{\mathrm{pm}^{2}}{\mathrm{~Pa}}
$$

onde:

$$
\begin{aligned}
\mathrm{R} & =\text { é o coeficiente de chuva em } \mathrm{mm} \\
\mathrm{pm} & =\text { é a precipitação média mensal em mm, } \\
\mathrm{Pa} & =\text { é a precipitação média anual em mm. }
\end{aligned}
$$

Os dados do Índice de exosividade médio mensal e do coeficiente de chuva foram ajustados a 12 tipos de modelos de regressão pré-defenidos, objetivando-se escolher a equação de regressão que melhor estimasse 0 Indice de erosividade médio mensal a partir de dados pluviométricos.

\subsubsection{Conversão de unidades}

A unidade $\mathrm{Tm} \cdot \mathrm{mm} / \mathrm{ha} \cdot \mathrm{h}$. ano tem sido usada na maioria dos trabalhos sobre erosividade das chuvas, entretanto para facilitar a comparação dos resultados obtidos, foram realizadas as conversões dos referidos dados para as unidades do Sistema Internacional. Os dados de erosividade da chuva obtidos em tm.mm/ha.h.ano foram multiplicadas pela constante 9.81 para se obter os respectivos dados em $\mathrm{MJ} \cdot \mathrm{mm} / \mathrm{ha} \cdot \mathrm{h} \cdot$ ano. 


\section{RESULTADOS E DISCUSSÕES}

\subsection{CORRELAÇõES}

\subsubsection{Correlações entre características físicas das chuvas erosivas e perdas de solo}

Para efeito de comparação são apresentados na tabela 1 os coeficientes de correlações entre características das chuvas e perdas de solo, correspondente ao período de 1975/76/78/79/80. Uma análise global dos coeficientes de correlação mostra que os coeficientes obtidos foram baixos variando de 0,2987 a 0,6689 , para as características da chuva I15 e PI60 respectivamente. Entretanto apesar de baixos, os coeficientes de correlações foram todos considerados estatisticamente significativos ao nível de $1 \frac{8}{8}$ de probabilidade.

A quantidade de chuva quando correlacionada com as perdas de solo apresentou um coeficiente de correlação muito baixo $(\mathrm{r}=0,3210)$. o valor do coeficiente obtido, entre a quantidade de chuva e perdas de solo é em termos absolutos menor do que os obtidos no Rio grande do Sul 
$(0,547$ a 0,631$)$ por MORAIS (1986), e em Mococa-SP $(r=0,661)$ por CARVALHO (1988), entretanto próximo do valor obtido para Campinas-SP $(x=0,44)$ por LOMBARDI NETO (1977) e semelhante ao valor obtido por BERTONI \& PASTANA (1964). As características da chuva do tipo (In) apresentaram coeficientes de correlação que variaram de 0,2987 a 0,5422 correspondente as caracteristicas I15 e I60 respectivamente. Os dados obtidos são semelhantes aos obtidos por BERTONI \& PASTANA (1964) e menores que os obtidos por BARNNETT (1958), MORAIS (1986) e CARVALHO (1987).

Em termos absolutos a intensidade máxima em 60 minutos (I60) apresentou um coeficinte de correlação $(x=$ 0,5422), maior do que os coeficientes de correlação obtidos para a energia cinética total $(r=0,4095)$ e $\mathrm{KE}>10 \quad(\mathrm{r}=$ $0,5195)$

o coeficiente de correlação obtido para a característica da chuva I60 foi menor do que os obtidos nos E.U.A $(r=0,768)$ por BARNNETT $(1958)$, em Campinas-SP $(r=$ 0,645) por LOMBARDI NETO (1977), no Rio grande do Sul (r = $0,663)$ por MORAIS $(1986)$ e em Mococa- SP $(r=0,7242)$ por CARVALHO (1988). Entretanto maior que os coeficientes de correlação obtidos por BERTONI \& PASTANA (1964) .

O coeficiente de correlação obtido para a intensidade máxima em 60 minutos (I60), quando comparado com as demais características do tipo (In) para tempos menores, indica que as perdas de solo em Caruaru-PE, estão 
relacionados a chuvas de longa duração.

A energia cinética total apresentou um baixo coeficiente de correlação $(I=0,4095)$. o coeficiente de correlação obtido neste trabalho foi menor que o obtido na Africa $(x=0,65$ a 0,85$)$ por LAL (1976), em Campinas-SP $(x=$ 0,55 ) por LOMBARDI NETO (1977), no Rio Grande do Sul ( $\mathrm{r}$ = 0.576 a 0,718$)$ por MORAIS $(1986)$ e em Mococa-SP $(r=0.7306)$ por CARVALHO (1987). O baixo coeficiente de correlação obtido para a relação energia cinética versus perdas de solo, mostra a necessidade de se desenvolver trabalhos de pesquisa objetivando obter equação entre energia cinética e intensidade mais ajustada às condições locais.

O baixo valor do coeficiente de correlação da energia cinética total pode ser explicado quando se considera - fato de que a equação de WISCHMEIER \& SMITH (1958), que foi desenvolvida a partir das condições climáticas dos E.U.A, ao ser aplicada em condições diferentes daquelas encontradas nos E.U.A, mormente naquelas existentes em climas tropicais, não representa satisfatoriamente a relação entre energia cinética e intensidade. Vários autores chamaram a atenção para o fato de que a equação de WISCHMEIER (1959) superestima a energia cinética quando aplicada em outras partes do mundo.(HUDSON, 1973; KINNEL, 1973; CARTER et alii, 1974 ; ZANCHI \& TORRI, 1980; LEPRUN, 1984 e ROTH et alii, 1984).

Segundo LEPRUN (1981) o emprego da equação de WISCHMEIER (1959) nas diferentes regiões do Brasil significa 
considerar que as chuvas do Brasil não somente são semelhantes aquelas dos E.U.A, como são semelhantes entre si, resultando sem dúvida em um erro. Vários autores constataram que a relação entre a distribuição de tamanho de gotas, intensidade e energia cinética é diferente para diferentes condições climáticas, atribuíndo estas diferenças ao tipo de chuva e a sua localização geográfica.(KINNEL, 1973; CARTER et alii, 1974 e ZANCHI \& TORRI, 1980).

As características da chuva do tipo (KEn) apresentaram coeficientes de correlação semelhantes, sendo que a característica $\mathrm{KE}>10$ apresentou um coeficiente de correlação $r=0,5195$, enquanto que a caracteristica $\mathrm{KE}>25$ apresentou um coeficiente de correlação de 0,5585 , sendo que estes resultados foram em geral menores do que os obtidos na Nigéria $(x=0,55$ a 0,83 para $K E>25)$ por LAL (1976), no Rio Grande do sul $(r=0,78$ e $r=0,641$ para $K E>10$ e $K E>25$ respectivamente) por MORAIS (1986) e em Mococa-SP ( $x=0,795$ e $r=0,788$ para $\mathrm{KE}>10$ e KE>25 respectivamente.) por CARVALHO (1987). Entretanto o valor do coeficiente de correlação da característica $\mathrm{KE}>25$ foi maior que a característica $\mathrm{KE}>25$ obtido por MEDINA (1987), para as condições de Manaus-AM ( $r$ = 0,41). Em termos absolutos a caracteristica da chuva do tipo $K E>n$ ocupou uma posição intermediária em relação as demais características da chuva. Neste caso, pode-se considerar que a eliminação dos valores da energia cinética das intensidades inferiores a $25 \mathrm{~mm} / \mathrm{h}$, melhorou a estimativa da erosividade, 
Tabela 1. Coeficiente linear (a), de regressão $(b)$ e de correlação das equaçôes de regressão linear simples entre as características físicas das chuvas e perdas de solo (t/ha). Analise de 80 chuvas ocorridas ea Caruaru-Pe no período de $1975 / 76 / 78 / 79 / 80$.

\begin{tabular}{|c|c|c|c|c|}
\hline \multirow{2}{*}{$\begin{array}{l}\text { NUMERO } \\
\text { DE } \\
\text { ORDEH }\end{array}$} & \multirow{2}{*}{$\begin{array}{l}\text { INDICES } \\
\text { OE } \\
\text { EROSIVIDADE }\end{array}$} & \multicolumn{2}{|c|}{ EQUAÇZO DE REGRESSZO } & \multirow{3}{*}{$\begin{array}{r}\text { COEFICIENTE OE } \\
\text { CORRELAG\%O ( } r) \\
1 / \\
n=80\end{array}$} \\
\hline & & \multirow[t]{2}{*}{$y=a$} & \multirow[t]{2}{*}{$+b$} & \\
\hline & & & & \\
\hline 1 & 115 & $-7,965 \cdot 10^{-3}$ & $6,815 \cdot 10^{-4}$ & $0,2987^{* *}$ \\
\hline 2 & PRECIPITACXO TOTAL & $-1,202 \cdot 10^{-2}$ & $1,095 \cdot 10^{-3}$ & $0,3210^{* *}$ \\
\hline 3 & 110 & $-1,174 \cdot 10^{-2}$ & $6,877 \cdot 10^{-4}$ & $0,3703^{* *}$ \\
\hline 4 & I5 & $-1,317 \cdot 10^{-2}$ & $5,490 \cdot 10^{-4}$ & $0,3948^{* *}$ \\
\hline 5 & ENERGIA CINETICA TOTAL & $-1,506 \cdot 10^{-2}$ & $5,859 \cdot 10^{-5}$ & $0,4095^{* *}$ \\
\hline 6 & PI15 & $-7,312 \cdot 10^{-3}$ & $2,926 \cdot 10^{-3}$ & $0,4492^{* *}$ \\
\hline 7 & EI5 & $-6,076 \cdot 10^{-3}$ & $9,996 \cdot 10^{-4}$ & $0,4621^{* *}$ \\
\hline 8 & 130 & $-1,704 \cdot 10^{-2}$ & $1,523 \cdot 10^{-3}$ & $0,488 \theta^{* *}$ \\
\hline 9 & PI10 & $-9,114 \cdot 10^{-3}$ & $2,676 \cdot 10^{-3}$ & $0,5185^{* *}$ \\
\hline 10 & KE>10 & $-1,230 \cdot 10^{-2}$ & $8,274 \cdot 10^{-5}$ & $0,5195^{* *}$ \\
\hline 11 & EI10 & $-7,513 \cdot 10^{-3}$ & $1,040 \cdot 10^{-3}$ & $0,5313^{* *}$ \\
\hline 12 & PIS & $-9,984 \cdot 10^{-3}$ & $2,072 \cdot 10^{-3}$ & $0,5419^{* *}$ \\
\hline 13 & 160 & $-2,001 \cdot 10^{-2}$ & $2,868 \cdot 10^{-3}$ & $0,5422^{* *}$ \\
\hline 14 & KE) 25 & $-9,910 \cdot 10^{-3}$ & $9,649 \cdot 10^{-5}$ & $0,5585^{* *}$ \\
\hline 15 & EI15 & $-6,218 \cdot 10^{-3}$ & $1,148 \cdot 10^{-3}$ & $0,5717^{* *}$ \\
\hline 16 & PI30 & $-1,905 \cdot 10^{-2}$ & $4,797 \cdot 10^{-3}$ & $0,5977^{* *}$ \\
\hline 17 & EI30 & $-8,885 \cdot 10^{-3}$ & $1,897.10^{-3}$ & $0,6161^{* *}$ \\
\hline 18 & EI60 & $-9,541 \cdot 10^{-3}$ & $3,344 \cdot 10^{-3}$ & $0,6221^{* *}$ \\
\hline 19 & PI60 & $-9,541 \cdot 10^{-3}$ & $3,344 \cdot 10^{-3}$ & $0,6689^{* *}$ \\
\hline
\end{tabular}

** Estatisticamente significativo ao nivel de $1 \%$ de probabilidade.

$1 / n=$ número de observąóes 
uma vez que, os valores dos coeficientes de correlação das características $\mathrm{KE}>10$ e energia cinética total foram menores.

As caracaterísticas do tipo (PIn) apresentaram coeficientes de correlação que variaram de 0,4492 a 0,6289 para as características PI15 e PI60 respectivamente. Em termos absolutos a caracaterística PI60 foi a que melhor se correlacionou com as perdas de solo de Caruaru-Pe. Comparando os valores obtidos por MORAIS (1986) no Rio Grande do Sul para as caracteristicas PI30 e PI10 ( $r=0,745$ e $r=0,761)$ respectivamente, as correlações obtidas em Caruaru-PE foram mais baixas. FOSTER et alii (1982) para as condições climáticas dos E.U.A, obtiveram coeficientes de correlação entre a característica PI30 e perda de solo, que variaram de $r=0,229$ a 0,788 respectivamente. LAL (1976) e MEDINA (1987), correlacionando várias características de chuva com perdas de solo, constataram que o índice PI7,5 foi o que melhor se correlacionou com as perdas de solo $(x=0,70$ a 0,86 e $r=0,73$ respectivamente.

- fato de que a característica da chuva PI60 tex apresentado em termos absolutos a melhor correlação com as perdas de solo, vem reforçar a afirmativa anterior apresentada na discussão da característica I60, de que, para as condições edafo-climáticas de Caruaru-PE, e especificamente do local do experimento, com solo arenoso e de boa drenagem, as perdas de solo estão mais associadas a 
chuvas com mais longa duração; condição em que a infiltração do solo diminui e aumenta o escoamento superficial. Deve-se acrescentar, que vários pesquisadores tem demonstrado que existe uma estreita correlação entre intensidade da chuva e perdas de solo, e que a quantidade de chuva pode explicar o fato de que uma chuva muito intensa mas de curta duração, pode resultar numa quantidade total de energia muito pequena e por conseguinte de pouca capacidade erosiva. (BARNNETT et àii, 1958; GREER 1971, HUDSON 1973 e LAL 1976).

As caracaterísticas da chuva do tipo (EIn), apresentaram coeficientes de correlação que variaram de $r=$ 0,4621 a 0,6621 para as caracteristicas EI15 e EI60 respectivamente. A característica EI30 apresentou a terceira melhor correlação com as perdas de solo $(x=0,6121)$, ficando abaixo das características EI60 e PI30 ( $r=0,6221$ e $r=0,6289$ respectivamente). Os dados obtidos por CARVALHO (1987), concernente as características EI30 e EI60 foram maiores ( $r=0,7992$ e $r=0,7996$ respectivamente) que os obtidos neste trabalho. MORAIS (1986), também obteve valores maiores para a característica EI30 $(r=0,759)$. O resultado obtido para a característica EI30 neste trabalho foi semelhante aos obidos em Campinas-SP $(r=0,67)$ por LOMBARDI NETO (1977) e em Manaus-AM $(r=0,64)$ por MEDINA (1987).

Apesar das restrições a característica EI30, por ter sido selecionada em clima temperado e pelas variações da energia cinética da chuva, que ocorrem entre diferentes 
regiões, esta característica vem se apresentando como um bom estimador das perdas de solo, como tem demonstrado diversos trabalhos já realizados nas condições edafo-climáticas do Brasil, sendo por isso utilizado para estimar $\circ$ potencial erosivo das chuvas no Brasil e em muitos países de clima tropical. (LOMBARDI NETO, 1977; BISCAIA et alii, 1981; MORAIS, 1986 e CARVALHO 1987).

WISCHMEIER (1978), chama a atenção para o fato dè que a capacidade da chuva de provocar erosão pode ser afetada a partir das interrelações de vários fatores tais como: umidade antecedente do solo, variações da intensidade durante a chuva, condições de umidade quando do preparo do solo. As interrelações destes fatores não controlados, que podem ocorrer de forma diferenciada para cada região, podem ter influenciado os resultados obtidos. KINNEL (1973); CARTER et alii (1974); e LEPRUN (1984) tem ressaltado que outros fatores podem influenciar os indices de erosividade do tipo (EIn), tais como: o tipo de chuva a localização geográfica, a temperatura, a estação do ano, a duração da chuva e o ângulo de inclinação de impacto das gotas de chuva.

MORAIS (1986), constatou que para três locais distintos, três indices de erosividade diferentes foram os que melhor se correlacionaram com as perdas de solos. Esse autor acrescenta que as condições edafoclimáticas próprias de cada local influenciaram os resultados obtidos para cada indice. Concordando com MORAIS (1986), STOCKING \& ELWELL 
(1973), ressaltam que as diferenças na capacidade potencial da chuva de provocar erosão expressa através de diferentes índices de erosão obtidos a partix de correlações com perdas de solo em diferentes locais, podem ser explicados pelas diferenças no tipo e origem das precipitações em várias regiões geográficas.

o modelo estatístico proposto por GRAYBILL (1961), utilizado para testar a homogeneidade entre os coeficiente de correlação possibilitou as seguintes conclusões:

a) não existe diferença significativa entre os coeficientes de correlação das características PI60 e Energia cinética total. Por conseguinte não existe também diferença significativa entre os coeficientes de correlação das seguintes características entre si: PI60 e EI30; EI30 e $\mathrm{KE}>10 ; \mathrm{KE}>10$ e KE>25; PI60 e KE>10; PI60 e KE>25; Energia cinética total e $\mathrm{KE}>10$; Energia cinética total e $\mathrm{KE}>25$.

b) existe diferença estatística ao nível de 5\% de probabilidade entre os coeficientes de correlação das características PI60 e Quantidade de chuva.

c) não existe diferença significativa entre os os coeficientes de correlação da energia cinética total e a quantidade de chuva.

d) não existe diferença significativa entre os coeficientes de correlação das características KE>25 e quantidade de chuva. 
e) existe diferença significativa ao nível de 5\% de probabilidade entre as características EI30 e a Quantidade de chuva.

f) existe diferença significativa ao nível de 1\% de probabilidade entre as características PI30 e I5.

Através do teste de homogeneidade, constatouse que não existe diferença estatística entre os coeficientes de correlação das características PI60 e Energia cinética total, ou seja, as diferenças entre os coeficientes de correlação compreendidos entre os coeficientes de correlação das característica PI60 e Energia cinética total pode ser atribuido ao acaso.

Apesar de que em termos absolutos a caracteristica PI60 ter sido a que melhor se correlacionou com as perdas de solo, a não existência de significância estatística entre os coeficientes de correlação das características PI60 e Energia cinética total torna estatisticamente 0 indice de erosividade EI30 igual ao Indice de erosividade PI60, visto que as diferenças em termos absolutos são atribuídas aos efeitos do acaso. Por conseguinte o Indice de erosividade EI30 pode estimar as perdas de solo causado pelas chuvas com mesma precisão que o PI60.

\subsection{DISTRIBUIÇÃO DO ÍNDICE DE EROSIVIDADE EI30 E DA PRECIPITAÇÃO}




\subsubsection{Distribuição dos Índices de erosividade EI30 anual e médio anual}

o número mínimo de anos considerados como aceitável obtido através da equação (15) foi de 20 anos, por conseguinte o número de anos utilizados para o cálculo do índice de erosividade de Caruaru-Pe, está dois anos abaixo dos limites estabelecida pela equação (15) •

Os valores médios mensais, anuais, e médio anual do índice de erosividade EI30 correspondente ao período de 1970 a 1989 estão apresentados na tabela 2. Deve-se ressaltar que foram excluídos os anos de 1977 e 1983, visto que nestes anos não foram registradas as chuvas através do pluviógrafo. O fator " $R$ " da equação universal de perdas de solo, expresso pelo valor médio dos índices de erosividade anuais foi de $2086 \mathrm{MJ} \cdot \mathrm{mm} / \mathrm{ha} \cdot \mathrm{h}$.ano.

A analíse estatistica correspondente aos valores dos 18 indices de erosividade anual apresentaram os seguintes resultados; a) desvio padrão de $1060 \mathrm{MJ} \cdot \mathrm{mm} / \mathrm{ha} \cdot \mathrm{h}$ b) erro padrão da média de $250 \mathrm{MJ} \cdot \mathrm{mm} / \mathrm{ha} \cdot \mathrm{h}$ c) coeficiente de variação de $51 \%$. O maior e o menor valor dos índices de erosividade anuais correspondente aos 18 anos de registro de chuva de Caruaru-Pe foram de 4003 e $458 \mathrm{MJ} \cdot \mathrm{mm} / \mathrm{ha} \cdot \mathrm{h}$, nos anos de 1972 e 1979 respectivamente.

o valor obtido para o indice de erosividade 


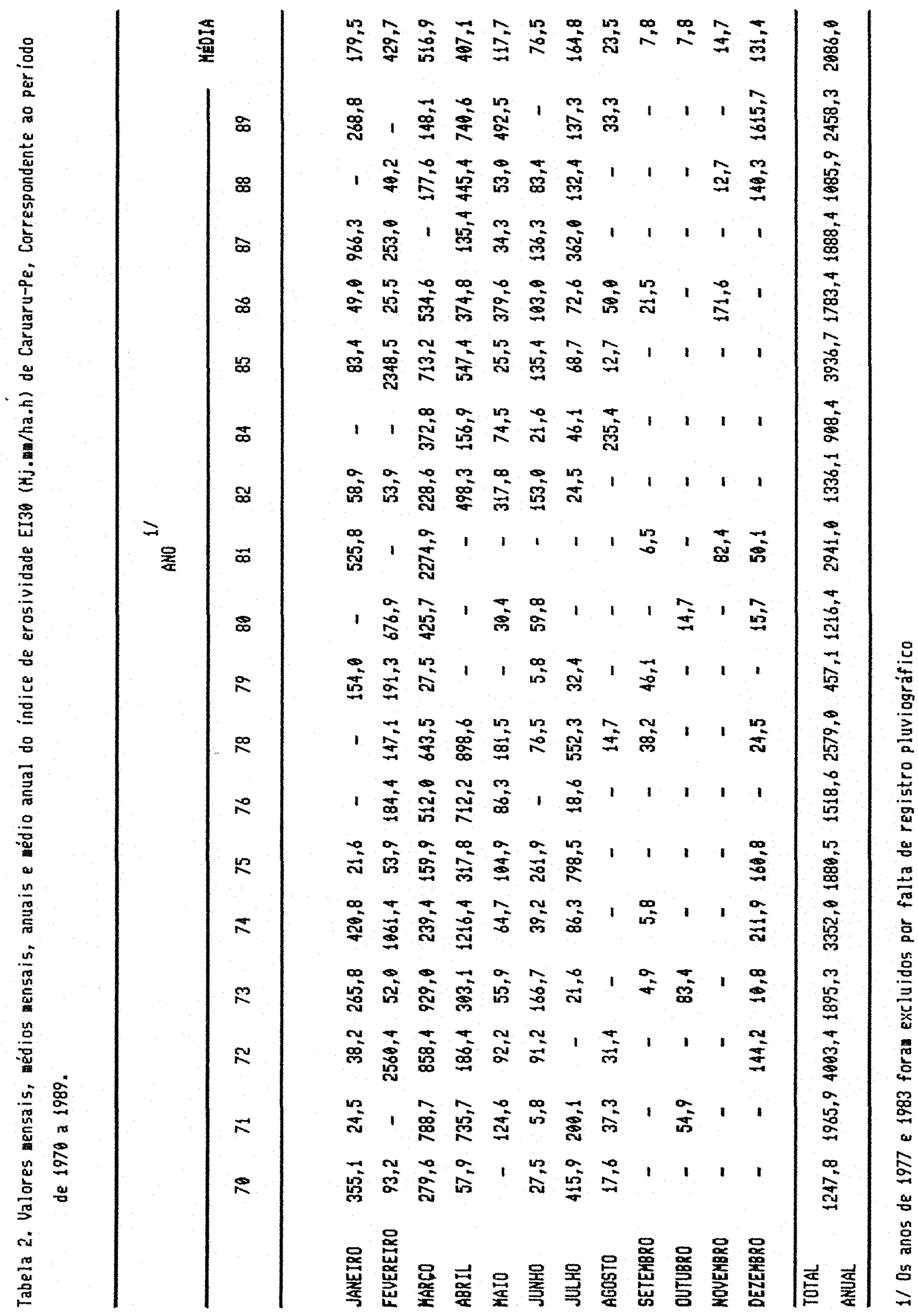


médio anual (Fator "R") de Caruaru-Pe é menor do aqueles obtidos em Campinas-SP (6769 MJ.mm/ha.h.ano) por LOMBARDI NETO (1977), em Brasilia-DF (8319 MJ.mm/ha.h.ano) por DEDECK (1978), em Piracicaba (5719 MJ.mm/ha.h.ano) por PEREIRA (1983), em Pelotas-RS (3924 Mj.mm/ha.h.ano) por LAGO (1984) e em Mococa-SP (7747 MJ.mm/ha.h.ano) por CARVALHO (1987).

CAMPOS FILHO (19841), obteve para o município de Glória do Goitá, localizado no agreste de Pernambuco um Indice de erosividade médio anual superior ao obtido neste trabalho (3483 MJ.mm/ha.h.ano).

CHAVES \& DINIZ (1981), obtiveram para 5 localidades do semi-árido paraibano, valores do índice de erosividade médios anuais maiores que os obtidos para Caruaru-Pe. (Texeira, $7818 \mathrm{MJ} . \mathrm{mm} / \mathrm{ha} \cdot \mathrm{h}$ ano; Itaporanga, 4150 MJ.mm/ha.h.ano; Bonito, $7534 \mathrm{MJ} \cdot \mathrm{mm} / \mathrm{ha} \cdot \mathrm{h}$. ano; Antenor, 4974 MJ.mm/ha.h.ano; e Catolé 6838 MJ.mm/ha.h.ano respectivamente). Os mesmos autores obtiveram para três localidades com precipitação pluviométrica média anual inferior as de Caruaru-Pe (Santa Rosa, $365 \mathrm{~mm}$; São Vivente, $411 \mathrm{~mm}$ e Taperoá $443 \mathrm{~mm}$ respectivamente), um índice de erosividade médio anual inferior ao obtido em Caruaru-Pe (Santa Rosa, 1462 MJ.mm/ha.h.ano); e dois índices de erosividade superiores ao obtido em Caruaru-Pe (São Vicente, 2776 MJ.mm/ha.h.ano e Taperoá 3198 MJ.mm.ha.h.ano) •

CHAVES \& DINIZ (1981), também calculou o valor médio anual do indice de erosividade EI30 de Guariba e Areia, 
obtendo valores de $4159 \mathrm{MJ} \cdot \mathrm{mm} / \mathrm{ha} \cdot \mathrm{h}$.ano e $3875 \mathrm{MJ} \cdot \mathrm{mm} / \mathrm{ha} \cdot \mathrm{h} \cdot$ ano respectivamente. O autor atribuiu os baixos valores do índice de erosividade médio anual de Areia, à presença de grande quantidades de chuvas de baixa intensidade durante o período mais chuvoso.

Como foi visto anteriormente, o indice de erosividade médio anual obtido para Caruaru- PE, quando comparado com os resultados obtidos para outras localidades com precipatação média anual semelhante ou mesmo quando comparado com os resultados obtidos para outras localidades com precipitação média anual menor do que a de Caruaru-Pe é considerado baixo. o baixo valor do índice de erosividade médio anual de Caruaru-Pe, pode ser explicado levando-se em consideração o fato de que ocorrem em Caruaru-PE um elevado chuvoso, como relatado por CHAVES \& DINIZ (1981) para o caso de Areias. Uma indicação dessa tendência pode ser vista na tabela 3, onde pode-se constatar que apenas 58\% da precipitação pluviométrica total foi utilizada no cálculo do Índice de erosividade. Essa percentagem é menor do que aquelas obtidas por LOMBARDI NETO (1977) e CARVALHO (1987) para Campinas-SP e Mococa-SP respectivamente.

o coeficiente de variação obtido a partir dos valores do índice de erosividade anual de Caruaru-Pe é maior que os obtidos em Campinas-SP $(35,8 \%)$ por LOMBARDI NETO (1977), em Piracicaba-SP $(26,6 \%)$ por PEREIRA (1983) e em Mococa-SP $(37,6 \%)$ por CARVALHO (1987). Entretanto o valor 
observado é semelhante aos valores obtidos por CHAVES \& DINIZ (1981) para Areias $(43,668)$. O alto valor do coeficiente de variação de Caruaru-Pe, indica uma grande variabilidade dos eventos estudados, sendo que este fato pode ser constatado na tabela 2, onde pode ser observado que há uma grande variação entre o maior e o menor valor do índice de erosividade anual $4003 \mathrm{MJ} \cdot \mathrm{mm} / \mathrm{ha} \cdot \mathrm{h}$. ano e 457 MJ.mm/ha.h.ano respectivamente.

o valor de $2086 \mathrm{MJ} . \mathrm{mm} / \mathrm{ha} . \mathrm{h}$. ano, obtido para o fator " $R$ " da equação universal de perdas de solo pode indicar a primeira vista que o risco de erosão na região de CaruaruPe é mínimo, entretanto uma única chuva em 1972, 1978 e 1979, sobre uma parcela experimental com 12\% de declividade e plantada com algodão herbáceo, sobre um Regossolo resultou em perdas de solo da ordem $8,2 \mathrm{t} / \mathrm{ha}, 5,4 \mathrm{t} / \mathrm{ha} e 2,65 \mathrm{t} / \mathrm{ha}$.

4.2.2. Distribuição mensal e estacional do índice de erosividade

Na tabela 4 estão apresentada a distribuição dos valores mensais, médio mensal e estacional do índice de erosividade EI30. Pode-se observar que os valores mensais começam a aumentar progressivamente de forma significativa a partir de dezembro mantendo essa tendência até março onde começa a decrescer. Os dados evidenciam que $81,5 \%$ do índice de erosividade médio anual ocorreu período de dezembro a 
Tabela 3. Valores da pluviometria total anual e pluviometria utilizada no calculo do índice de erosividade médio anual.

\begin{tabular}{|c|c|c|c|}
\hline AND & $\begin{array}{l}\text { PRECIP ITACAO } \\
\text { PLUUIOHETRICA } \\
\text { TOTAL } \\
\text { (Ma) }\end{array}$ & $\begin{array}{l}\text { PRECIPITACZO PLUUIOMÉTR ICA } \\
\text { UTILIZADA NO CALCULO DO EIJO } \\
\text { (ax) }\end{array}$ & $\begin{array}{c}\text { INDICE DE } \\
\text { EROSIVIDADE } \\
\text { EI30 } \\
(M J . m \text {.ha.h.ano) }\end{array}$ \\
\hline 1970 & 696,1 & 460,4 & 1247,8 \\
\hline 1971 & 620,1 & 353,1 & 1965,9 \\
\hline 1972 & 688,4 & 431,3 & 4063,4 \\
\hline 1973 & 665,7 & 369,8 & 1895,3 \\
\hline 1974 & 912,1 & 724,6 & 3352,0 \\
\hline 1975 & 750,5 & 412,5 & 1880,6 \\
\hline 1976 & 634,6 & 294,6 & 1518,6 \\
\hline 1978 & 899,0 & 513,4 & 2579,0 \\
\hline 1979 & 466,0 & 170,1 & 457,1 \\
\hline 1980 & 634,6 & 326,5 & 1216,4 \\
\hline 1981 & 647,6 & 396,1 & 2941,0 \\
\hline 1982 & 632,1 & 301,1 & 1336,2 \\
\hline 1984 & 700,5 & 297,8 & 998,4 \\
\hline 1985 & 939,7 & 599,9 & 3936,7 \\
\hline 1986 & 932,1 & 574,1 & 1783,4 \\
\hline 1987 & 547,6 & 270,8 & 1888,4 \\
\hline 1988 & 702,4 & 435,4 & 1085,9 \\
\hline 1989 & 869,2 & 565,7 & 2458,3 \\
\hline MÉDIA & 718,8 & 416,5 & 2986,0 \\
\hline
\end{tabular}


abril, sendo que no mesmo período ocorreu $47,23 \%$ da precipitação pluviométrica.

No trimestre correspondente aos meses de fevereiro, março e abril ocorrem $65 \%$ do índice de erosividade médio anual e $38 \%$ da precipitação média anual No trimestre correspondente aos meses de maio, junho e julho ocorrem $17,3 \%$ do Índice de erosividade médio anual e 38\% da precipitação média anual. A adição do trimestre fevereiro-março-abril ao trimestre maio-junho-julho eleva o Índice de erosividade médio anual e a precipitação média anual para $82,4 \%$ e $75,4 \%$ respectivamente.

Na tabela 4 e figura 3, podem ser observados a distribuição percentual dos valores do índice de erosividade médio mensal em relação ao índice de erosividade médio anual e da precipitação média mensal em relação a precipitação média anual. Os dados evidenciam que os valores percentuais do índice de erosividade médio anual não apresentam uma distribuição semelhante aos dos valores percentuais da precipitação média anual. Numa análise mais detalhada, pode-se constatar que nos meses de janeiro, fevereiro, março e abril os valores percentuais do índice de erosividade médio anual são maiores que os valores percentuais da precipitação. Pode-se observar também que para - período de janeiro, fevereiro, março e abril há uma concordância entre a distribuição dos valores percentuais do Indice de erosividade médio anual e os valores percentuais 
Tabela 4. Valores percentuais mensais e estacional do índice de erosividade médio anual $E$ da precipitação média anual de Caruaru-Pe, correspondente ao períado de 1970 a 1989.

\begin{tabular}{|c|c|c|c|}
\hline MÊSS & 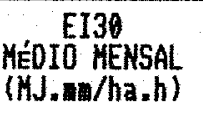 & $\begin{array}{l}\text { PERCENTAGEM DO EI30 } \\
\text { MEDIO ANUAL }\end{array}$ & $\begin{array}{c}\text { PERCENTAGEM DA PRECIPITACZO } \\
\text { MEOIA ANUAL }\end{array}$ \\
\hline JANEIRO & 185,3 & 8,62 & 5,33 \\
\hline FEVEREIRO & 430,3 & 20,68 & 8,40 \\
\hline HARCO & 517,5 & 24,88 & 13,94 \\
\hline ABRIL & 407,1 & 19,57 & 15,67 \\
\hline MAIO & 117,1 & 5,66 & 11,14 \\
\hline JUNHO & 76,6 & 3,68 & 11,32 \\
\hline JULHO & 165,1 & 7,93 & 15,24 \\
\hline AG0STO & 24,0 & 1,15 & 7,09 \\
\hline SETEMBRO & 8,1 & 0,39 & 3,60 \\
\hline OUTUBRO & 8,4 & 0,40 & 2,70 \\
\hline NOUEMBRO & 14,9 & 0,71 & 2,13 \\
\hline DEZEMBRO & 131,9 & 6,34 & 3,89 \\
\hline $\begin{array}{l}\text { UERZO } \\
(01.12 \text { a } 27.02)\end{array}$ & $37,14 \%$ & & \\
\hline $\begin{array}{l}\text { OUTONO } \\
(01.03 \text { a } 30.05)\end{array}$ & $50,11 \%$ & & \\
\hline $\begin{array}{l}\text { INUERND } \\
(01.06 \text { a } 03.08\rangle)\end{array}$ & $12,76 \%$ & & \\
\hline $\begin{array}{l}\text { PRIMAUERA } \\
(01.09 \text { a } 30.11)\end{array}$ & 1,507 & & \\
\hline
\end{tabular}


da precipitação média anual, ou seja os maiores valores percentuais do índice de erosividade média mensal apresentam comportamento semelhante aos dos maiores valores percentuais da precipitação para esse período. Entretanto para os meses de maio, junho e julho, quando os valores percentuais da precipitação média anual são semelhantes ao do período de fevereiro, março e abril, os valores percentuais do índice de erosividade médio anual são menores chegando em termos absolutos a no máximo $50 \%$ dos valores percentuais da precipitação média anual. Nesse período pode-se constatar que os valores percentuais do índice de erosividade médio anual não apresentam a mesma tendencia da precipitação média anual, ou seja o período de maio junho e julho que apresentam um percentual de chuvas semelhantes aos do período de fevereiro, março e abril, apresenta valores percentuais do Índice de erosividade médio anual muito baixos em relação ao período de fevereiro, março e abril, ou seja não há uma concordância entre os valores da precipitação e os valores do Índice de erosividade.

Para o período de dezembro a abril onde os valores percentuais do índice de erosividade foram superiores aos da precipitação média anual, o mês de março foi o que apresentou o maior valor, sendo superior ao valor da precipitação em torno de $44 \%$. Para o período de maio a novembro, onde os valores percentuais da precipitação média anual superam os valores percentuais do indice de 

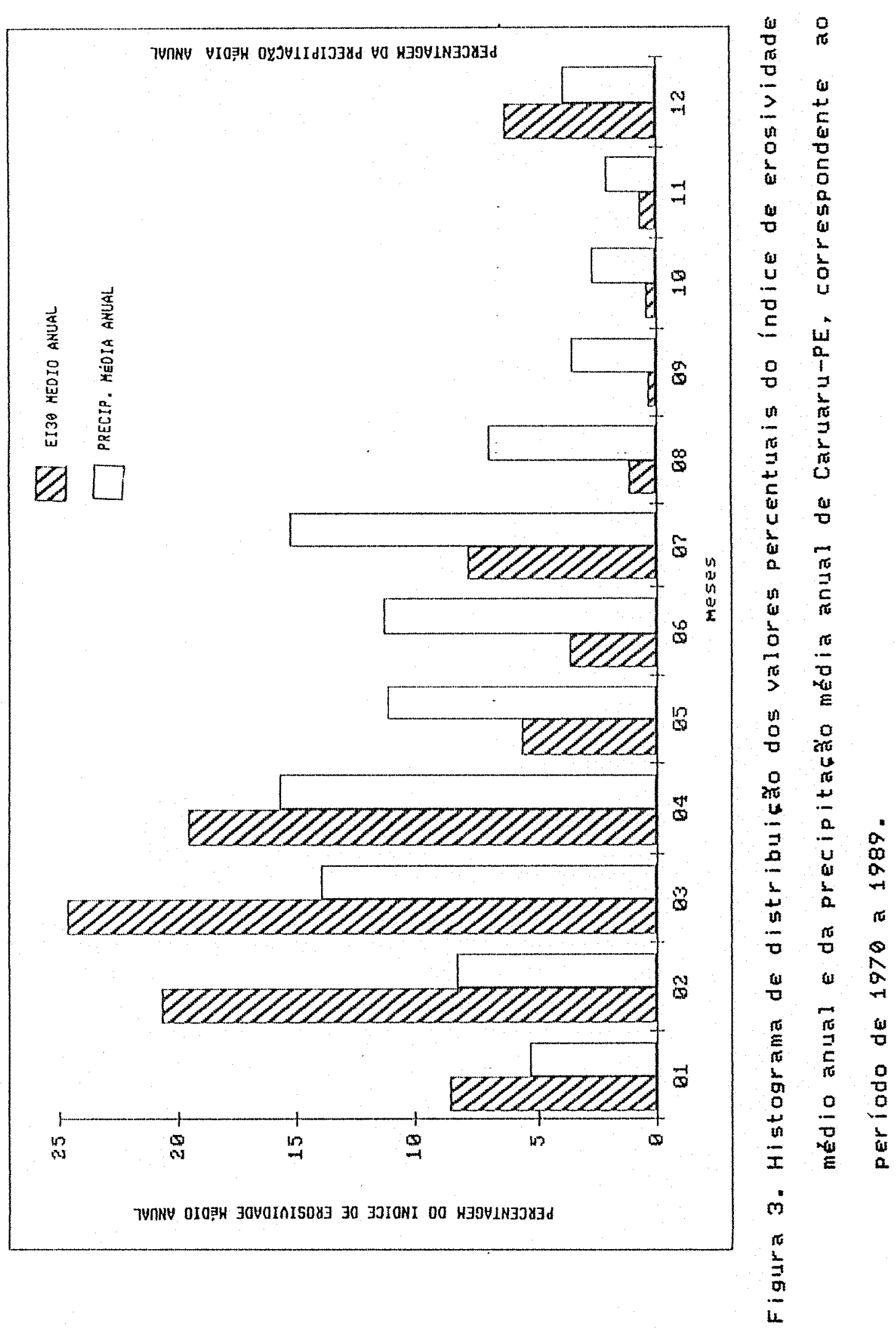
erosividade médio anual, o mês de julho que é o mais chuvoso nesse pexiodo, representa em termos absolutos apenas $50 \%$ da precipitação média mensal no referido mês.

$\mathrm{Na}$ figura 4 , onde as escalas foram ajustadas para fins de comparação, pode-se observar a distribuição dos valores do indice de erosividade médio anual e da precipitação média anual. A distribuição dos valores do Índice de erosividade médio anual nos meses de janeiro, fevereiro e março, é semelhante a distribuição dos valores da precipitação média anual nesse período que é um dos mais chuvosos. Entretanto, para o período correspondente a abril, maio junho e julho, o mesmo comportamento não ocorre, ou seja, apesar desse período ser o mais chuvoso, a distribuição dos valores dos índice de erosividade médio anual do período correspondente a abril, maio, junho e julho diferem completamente da distribuição dos valores da precipitação média anual, ficando em termos relativos bem abaixo dos valores da precipitação média anual.

A constatação de que no período de dezembro a abril os valores percentuais do índice de erosividade médio anual são superiores aos valores percentuais da precipitação média anual, é uma indicação de que nesse período, mormente no período comprendido entre fevereiro e abril, predominam chuvas de maior capacidade erosiva do que as que ocorrem no resto do ano. Para o período de maio, junho e julho, em que as chuvas atingem valores semelhantes ao periodo de 


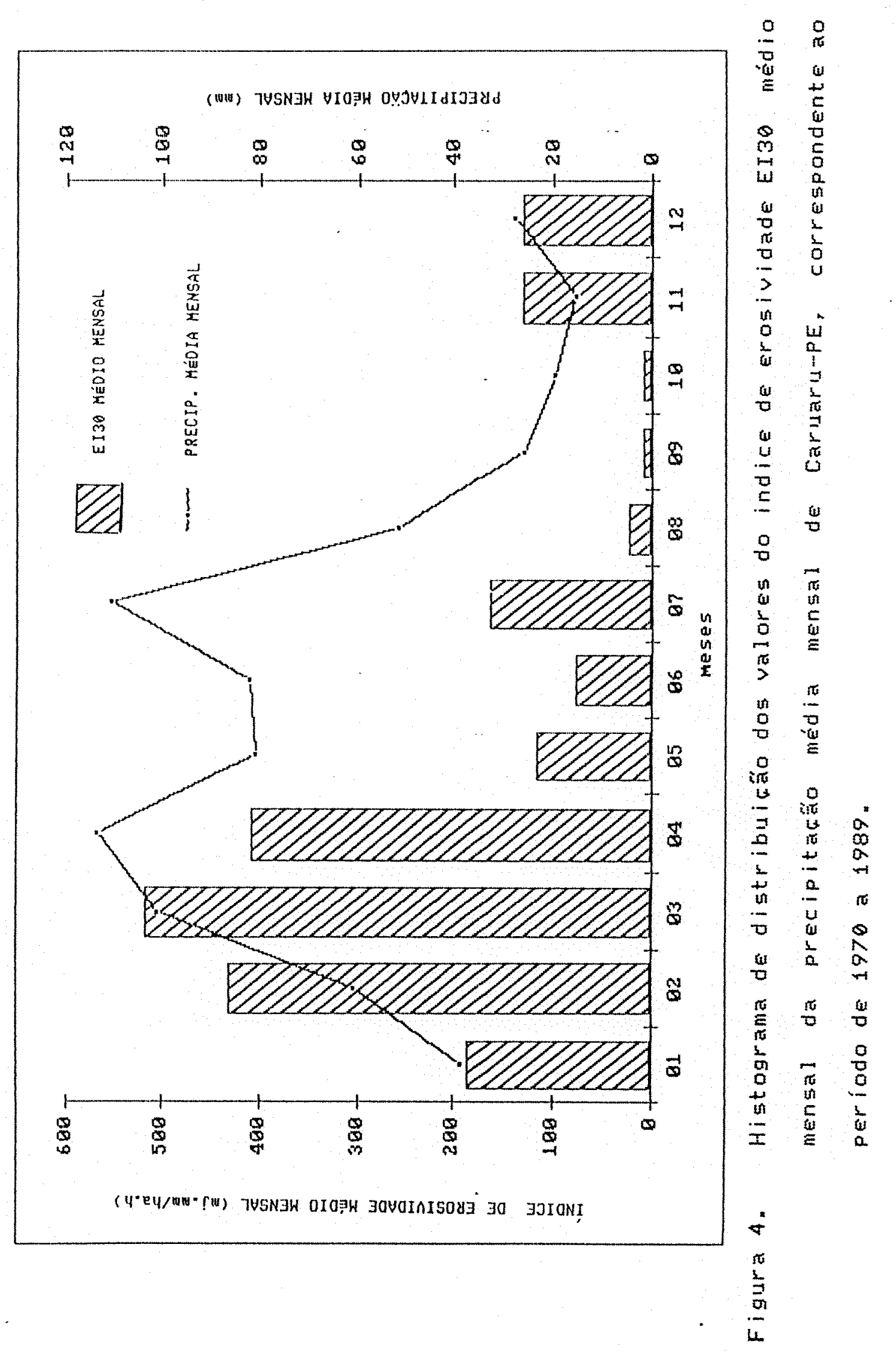


fevereiro, março e abril, pode-se constatar que os valores do índice de erosividade médio anual representam menos da metade dos valores da precipitação médio anual, indicando a ocorrência de chuvas de baixa capacidade erosiva, concordando com CHAVES (1978). Constatou-se através de dados obtidos na estação experimental de Caruaru-PE, que mais de $70 \%$ das perdas de solo da parcela descoberta em estudo, ocorrem no período de fevereiro, março e abril, ao passo que no período de maio, junho e julho quando as precipitações são semelhantes ao do período de fevereiro, março e abril as perdas são pequenas indicando a presença de chuvas de baixa capacidade erosiva o que é explicado pela análise comparativa da distribuição percentual do indice de erosividade e da precipitação.

A ocorrência de $81,5 \%$ do valor do índice de erosividade médio anual entre os meses de dezembro a abril, indica que neste período ocorrem os maiores riscos de erosão, mormente no trimestre fevereiro-março-abril, quando ocorrem $65,3 \%$ desse índice e por conseguinte pode ser esperado os maiores riscos de perda de solo.

O mês de março é o período em que o índice de erosividade médio mensal atinge o maior valor (517 MJ.mm/ha.h.ano), representando 24,38 do indice de erosividade médio anual. O mês de setembro é o período em que - Indice de erosividade médio mensal atinge o seu menor valor (8 $\mathrm{MJ} \cdot \mathrm{mm} / \mathrm{ha} \cdot \mathrm{h} \cdot \mathrm{ano})$, representando $0,3 \%$ do índice de 
erosividade médio anual. Por conseguinte a maior e a menor expectativa de perda de solo para Caruaru-Pe provavelmente ocorrerão em março e setembro respectivamente.

A tabela 4 mostra a distribuição estacional do Indice de erosividade médio anual. Pode-se observar que o verão e o outono são as estações de mais elevada erosividade contribuíndo com $37 \%$ e $50 \%$ do valor médio anual de erosividade, enquanto que a primavera é a estação de menor erosividade, concordando com CHAVES \& DINIZ (1981). Entretanto diferem dos dados obtidos por LOMBARDI NETO (1977) e CARVALHO (1988).

\subsubsection{Distribuição da precipitação pluviométrica}

$\mathrm{Na}$ tabela 5 podem ser observados os valores correspondentes a precipitação mensal, média mensal, anual e média anual, ocorrida em Caruaru-Pe no período de 1970 a 1989.

A análise estatística dos valores da precipitação pluviométrica anual, apresentaram os seguintes resultados: a) desvio padrão de $152,30 \mathrm{~mm}$ b) erro padrão da média de $34 \mathrm{~mm}$ c) coeficiente de variação de 21 \% e d) média de $719 \mathrm{~mm}$.

Na tabela 3 pode-se observar que do total de chuvas ocorridas em Caruaru-Pe, somente $58 \%$ foram utilizadas no cálculo do índice de erosividade, indicando a presença de 


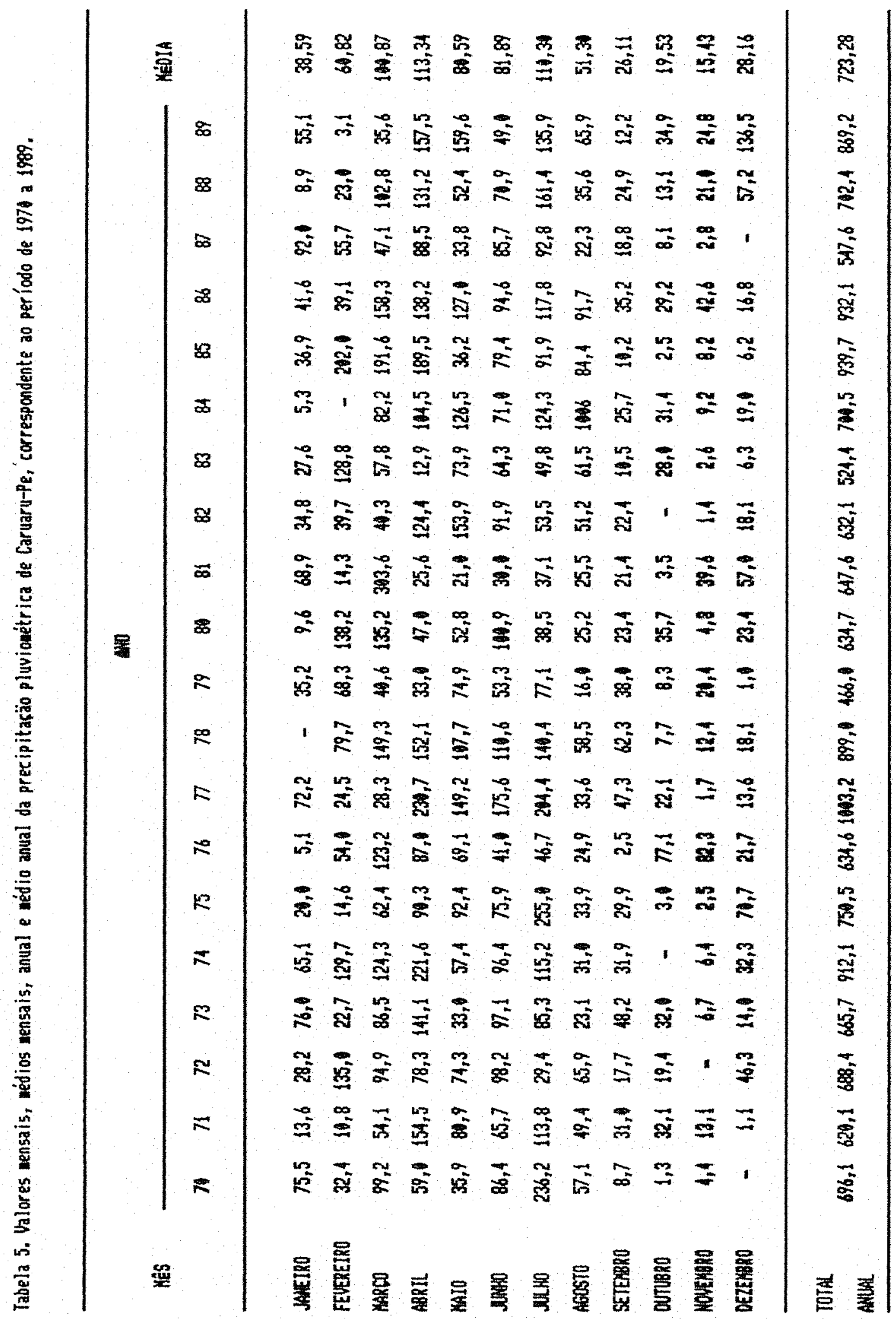


grandes quantidades de chuvas de baixa capacidade erosiva.

$\mathrm{Na}$ tabela 5 pode-se observar que $76 \%$ das chuvas ocorrem nos meses de março a agosto. No período compreendido entre setembro a janeiro as chuvas são muito escassas, correspondendo a apenas 248 do total médio anual.

\subsubsection{Curva de distribuição do índice de erosividade $\operatorname{Ex} 30$}

A figura 5 apresenta a distribuição percentual acumulada do índice de erosividade médio anual. 0 indice de erosividade médio anual (Fator "R"), indica a capacidade erosiva da chuva para uma determinada região, entretanto essa informação por si só não é suficiente para avaliar a capacidade potencial das chuvas de provocar erosão no decorrer do ano, sendo por conseguinte, de grande importância prática o conhecimento da distribuição do índice de erosividade médio anual, mormente na determinação do Fator Uso e Manejo do Sistema Produtivo da equação universal de perdas de solo.

$\mathrm{Na}$ figura 5 pode ser observado que o período em que a curva apresenta maior inclinação corresponde aos meses de fevereiro, março e abril, período em que ocorrem os maiores valores do indice de erosividade médio anual. 

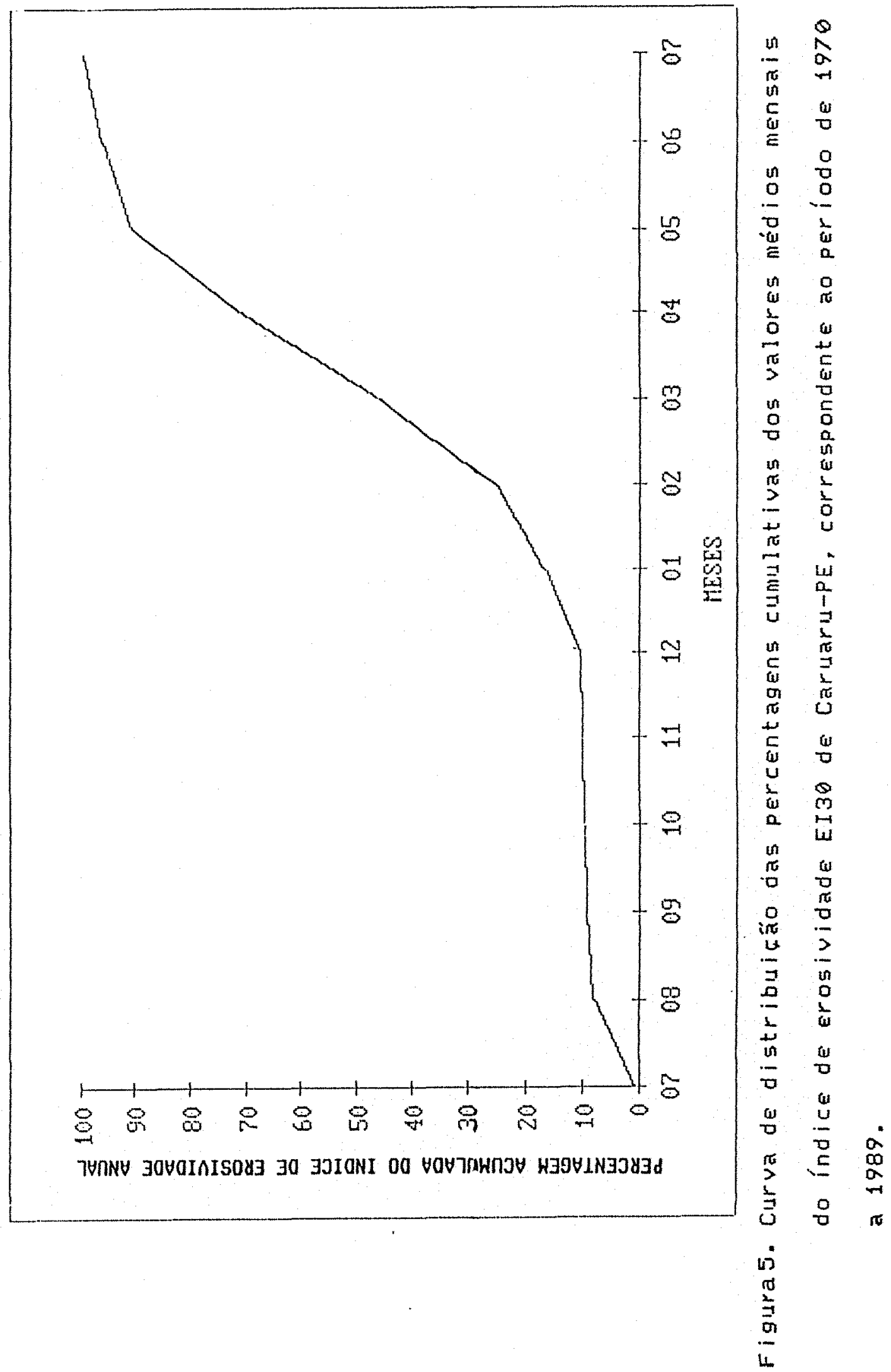


\subsubsection{Probabilidade de ocorrência e período de retorno dos valores do indices de erosividade anual}

A probabilidade de ocorrência e o período de retorno, dos valôres do índice de erosividade anual de Caruaru-Pe, correspondente ao período 1970 a 1989 estão apresentados na tabela 6 e figura 6 . Pode-se observar que para o maior valor observado do índice de erosividade anual $4003 \mathrm{MJ} . \mathrm{mm} / \mathrm{ha} \cdot \mathrm{h}$. ano, a probabilidade de ocorrência foi de $4,8 \%$ e o período de retorno de 21 anos. Para o menor valor do indice de erosividade anual $457 \mathrm{MJ} . \mathrm{mm} / \mathrm{ha} \cdot \mathrm{h}$. ano a probabilidade de ocorrência foi de $95,8 \%$ e 0 período de retorno de 1,05 anos.

$\mathrm{Na}$ figura 6 pode-se observar a curva de distribuição da probabilidade de ocorrência obtida a partir dos valores observados, enquanto que os valores teóricos estão representados pela reta de ajustamento.

Com a inclusão dos anos de 1977 e 1983, a média dos valôres do indice de erosividade anual passou a ser de 2040 MJ.mm/ha.h.ano, enquanto que os valores extremos mantiveram-se os mesmos apesar da inclusão dos anos de 1977 e 1983 ou seja $4003 \mathrm{MJ} \cdot \mathrm{mm} / \mathrm{ha} \cdot \mathrm{h}$. ano e 457 MJ.mm/ha.h.ano respectivamente.

Através da equação (13) foram calculados os correspondente aos períodos de retorno de $2,5,20$ e 100 
Tabela 6. Probabilidade de ocorrência e periodo de retorno (ano) dos valores dos indices de erosividade anuais (MJ.mm/Ha.h.ano) de Caruaru-PE, correspondente ao periodo de 1970 a 1989.

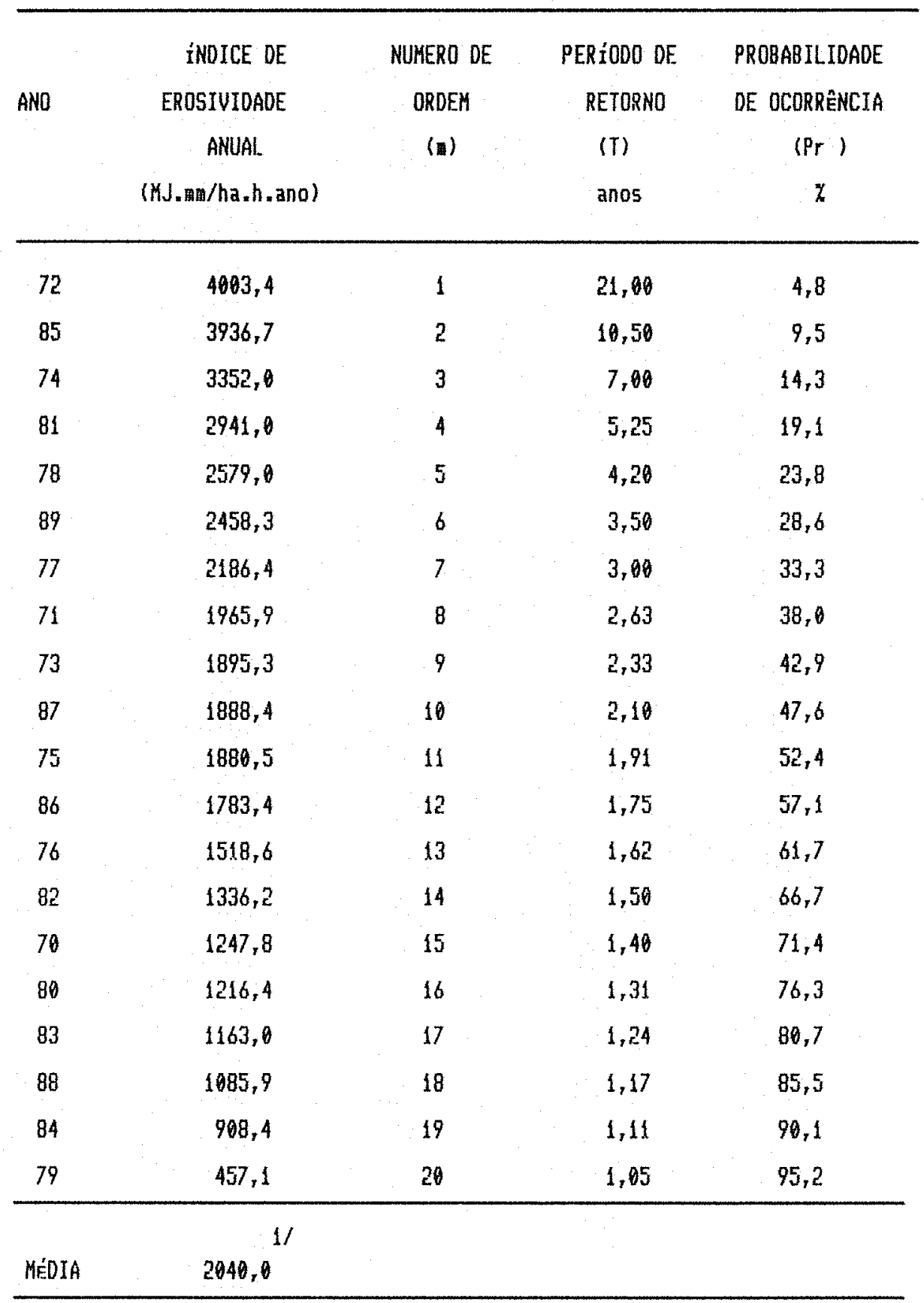

1/ Incluidos os anos de 1977 e 1983 respectivamente. 
anos respectivamente. Os valores teóricos obtidos para os períodos de retorno de 2, 5,20 e 100 anos foram os seguintes: 1852 MJ.mm/ha.h.ano, 2777 Mj.mm/ha.h.ano 4097 MJ.mm/ha.h.ano e 5703 MJ.mm/ha.h.ano.

Em termos absolutos o valor médio anual (2086 MJ.mm/ha.h.ano) do Índice de erosividade EI30 apresentou uma probabilidade de ocorrência de $41,6 \%$ e um período de retorno de 2,4 anos, indicando que é esperado que ocorra um valor igual ou superior $2806 \mathrm{MJ} . \mathrm{mm} / \mathrm{ha} \cdot \mathrm{h}$ a cada 2,4 anos.

$\mathrm{Na}$ figura 6 pode-se constatar também que a distribuição dos valores do índices de erosividade anuais, seguem o padrão log-normal, concordando com LOMBARDI NETO (1977), SCHWAB et alii (1981) e CARVALHO (1987).

o conhecimento da distribuição da probabilidade de ocorrência dos valores dos índices de erosividade anuais tem importância prática, visto que as recomendações conservacionistas podem ser feitas com base em qualquer nível de probabilidade com os valores teóricos do indice de erosividade anual, obtidos diretamente através da curva de distribuição de probabilidade.

o maior valor do Índice de erosividade anual observado para Caruaru-PE $4003 \mathrm{MJ} \cdot \mathrm{mm} / \mathrm{ha} \cdot \mathrm{h} \cdot$ ano apresentou um período de retorno de 21,0 anos e uma probabilidade de ocorrência de 4,8 8 respectivamente, indicando que é esperado que ocorra um valor igual ou superior a $4003 \mathrm{MJ} \cdot \mathrm{mm} / \mathrm{ha} \cdot \mathrm{h} . \mathrm{ano}$ pelo menos uma vez a cada 21 anos. O menor valor do índice de 


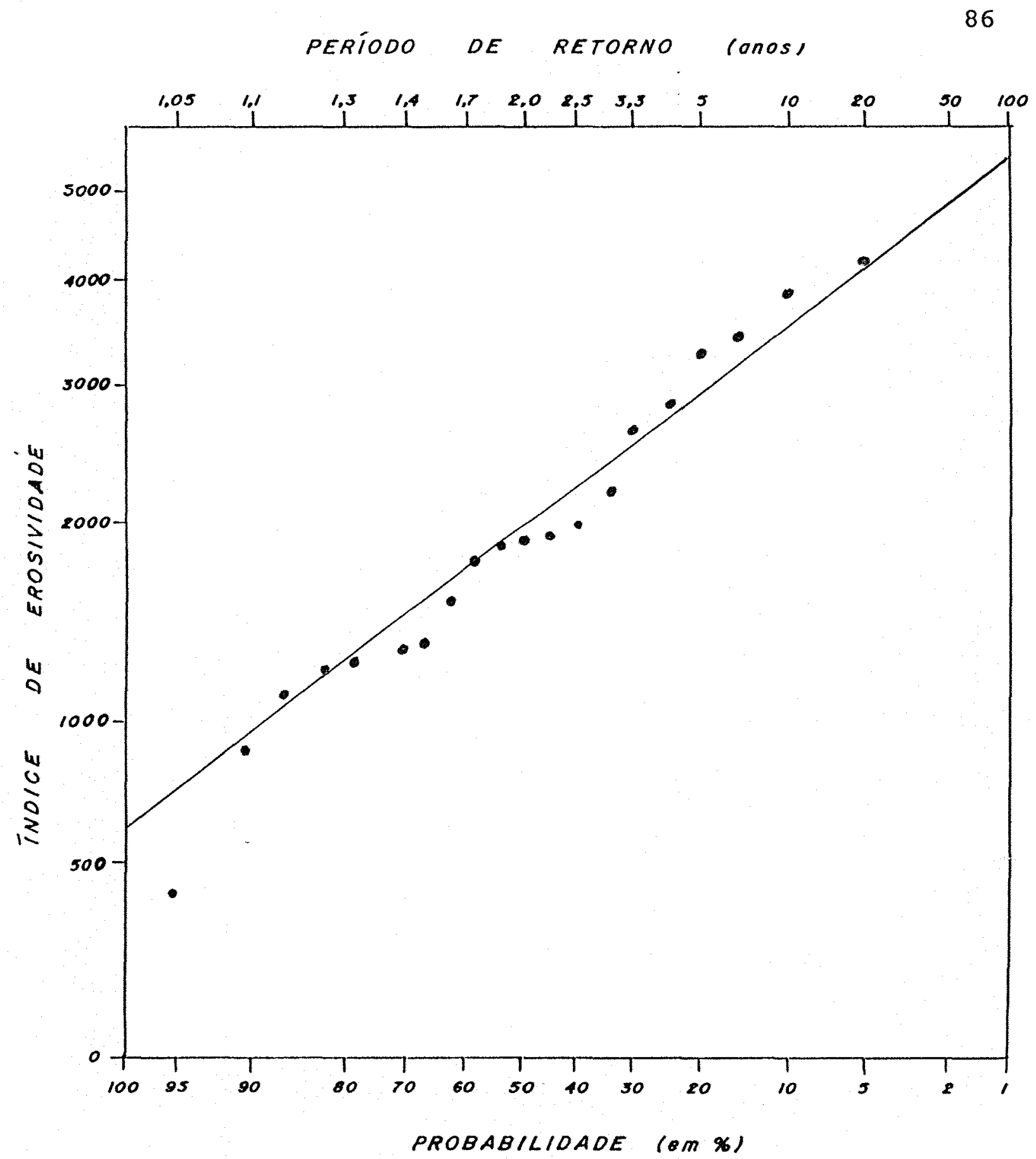

figura 6. Curva de distribuicáo de probabilidade de ocorrência dos valores do índice de erosividade anual (MJ.mm/ha.h.ano) de Caruaru-PE, correspondente ao período de 1970 a 1989. 
erosividade anual observado para Caruaru-Pe

MJ.mm/ha.h.ano). apresentou um período de retorno de 1,05 anos e uma probabilidade de ocorrência de 95,28 respectivamente, indicando que é esperado que ocorra um valor igual ou superior a $457 \mathrm{Mj} \cdot \mathrm{mm} / \mathrm{ha} \cdot \mathrm{h}$. ano a cada 1,05 anos.

4.3. Estimativa do índice de erosividade médio mensal a partír de dados pluviométricos

A tentativa de se estimar os valores dos indices de erosividade médios mensais a partir de dados pluviométricos para a região de Caruaru-Pe tem como justificativa três fatos a saber: a) a baixa densidade de pluviógrafo existente na região, b) o número considerável de pluviômetros existentes na região e c) o cálculo do índice de erosividade EI30 médio anual é exaustivo e moroso quando calculados a partir de pluviogramas.

o ajuste dos dados dos indice de erosividade médios mensais e do coeficiente de chuva a 12 modelos predefinidos de regressão indicou que a equação de regressão que melhor se ajustou aos dados foi a do tipo potencial, abaixo mencionada:

$$
\operatorname{EI} 30=30,06\left(p^{2} / P\right)^{0,809} \quad r=0,6125
$$

onde: 


$$
\begin{aligned}
& \text { EI30 = Índice de erosividade médio mensal em } \\
& \text { MJ.mm/ha.h } \\
& \mathrm{p}=\text { precipitação média mensal em mm } \\
& \mathrm{P}=\text { precipitação média anual em mm } \\
& \text { O coeficiente de correlação obtido entre os }
\end{aligned}
$$

Índices de erosividade médios mensais e o coeficiente de chuva é considerado baixo $(0,6125)$. Estes resultados diferem daqueles obtidos por LOMBARDI NETO (1977), PEREIRA (1983) e CARVALHO (1987) .

Os valores correspondentes aos coeficientes de chuva, índice de erosividade médio mensal e índice de erosividade médio mensal estimado podem ser observados na tabela 7 .

Os dados obtidos mostram que não há uma correspondência proporcional entre a variação dos valores dos coeficientes de chuva e dos índices de erosividade médio mensal, diferindo dos dados obtidos por LOMBARDI NETO (1977), PEREIRA (1983) e CARVALHO (1987) . Numa análise mais detalhada pode-se observar que quando se coloca os valores dos índices de erosividade médios mensais e os valores dos coeficientes de chuva em ordem decrescente, pode-se observar que a medida que os valores dos coeficientes de chuva decrescem, os valores dos índices de erosividade médio mensal não decrescem proporcionalmente, afetando por conseguinte a correlação entre os valores do indices de erosividade médios mensais e os valores dos coeficientes de chuva, resultando portanto em baixos valores do coeficiente de correlação e de 
determinação respectivamente.

Pode-se concluir portanto, que para locais com características climáticas semelhantes a de Caruaru-Pe onde øó existam pluviômetros a equação obtida a partir de dados pluviométricos não é capaz de estimar o índice de erosividade médio mensal como pode ser visto na tabela 7 , onde a equação obtida subestimou o Índice de erosividade médio mensal em torno de 26 용. 
Tabela 7. Valores correspondente ao indice de erosividade médio mensal, coeficiente de chuva $e$ indice de erosividade médio mensal estimado.

\begin{tabular}{|c|c|c|c|}
\hline HÊS & $\begin{array}{l}\text { COEFICIENTE } \\
\text { DE CHUUA } \\
\text { (ax) }\end{array}$ & $\begin{array}{c}\text { INDICE DE EROSIVIDADE } \\
\text { KEDDIO MENSAL } \\
(\text { MJ.mu/ha.h) }\end{array}$ & 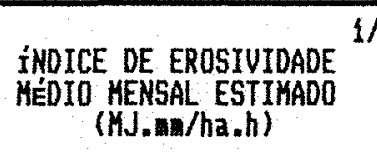 \\
\hline JANEIRO & 2,05 & 185,3 & 54,9 \\
\hline FEVEREIRO & 5,11 & 430,2 & 112,3 \\
\hline MARCO & 14,06 & 517,5 & 254,6 \\
\hline ABRIL & 17,76 & 407,1 & 307,7 \\
\hline HAIO & 8,97 & 117,7 & 177,0 \\
\hline JUNHO & 9,27 & 76,6 & 158,2 \\
\hline JULHO & 16,82 & 165,1 & 294,6 \\
\hline AGOSTO & 3,63 & 24,0 & 85,1 \\
\hline SETEMBRO & 0,94 & 8,1 & 28,5 \\
\hline DUTUBRO & 0,52 & 8,4 & 17,6 \\
\hline NOUEABRO & 0,32 & 14,9 & 11,9 \\
\hline DEZEMBRO & 1,09 & 131,9 & 32,2 \\
\hline $\begin{array}{l}\text { NÉDIA } \\
\text { ANUAL }\end{array}$ & & 2086,0 & 1534,0 \\
\hline
\end{tabular}

$1 / E I 30=30,01\left(p^{2} / p\right)^{0,809}$ 


\section{CONCLUSÕES}

$\mathrm{Na}$ condição em que o presente trabalho foi realizado, com os materiais e métodos empregados e em decorrência dos resultados obtidos, analisados e interpretados, estabelecem-se as conclusões a seguir apresentadas.

1. Em termos absolutos a característica da chuva PI60 é a melhor correlacionada com as perdas de solo. Entretanto a aplicação do teste de homogeneiddade indicou que as diferenças entre as características da chuva PI60 e EI30 é meramente devida ao acaso e por conseguinte a característica EI30 pode ser indicada como indice de erosividade, da mesma forma que a caracteristica PI60.

2. Pode-se recomendar o indice de erosividade EI30 como adequado para estimar as perdas de solo em Caruaru$\mathrm{PE}$, pois trata-se de um índice de erosividade conhecido e cuja aplicação no Brasil já é amplamente divulgada.

3. O indice de erosividade EI30 (Fator "R" da equação universal de perdas de solo), apresenta em Caruaru-PE um valor médio anual de $2086 \mathrm{MJ} \cdot \mathrm{mm} / \mathrm{ha} \cdot \mathrm{h}$.ano 
4. o trimestre correspondente a fevereiro, março e abril é o que apresenta o maior risco de erosão, visto que neste período ocorreram $65 \%$ do valor do índice de erosividade médio anual e 388 da precipitação média anual, sendo necessário sobretudo nesse período maiores cuidados conservacionistas no sentido de evitar grandes perdas de solo.

5. A correlação entre o Índice de erosividade médios mensais e os coeficiente de chuva resultou num baixo coeficiente de correlação. A equação de regressão é considerada insatisfatória para estimar o indice de erosividade médio mensal e por conseguinte o índice de erosividade médio anual, para locais com condições climáticas semelhantes as de Caruaru-Pe e onde não existam pluviógrafos, mas somente pluviômetros. 


\section{REFERÊNCIAS BIBLIOGRÁFICAS}

BARNETT, A.P. How intense rainfall affects runoff and soil erosion. Agricultural Engineering, St. Joseph, 39: 703-7, $711,1958$.

BERTONI, J. Sistemas coletores para determinação de perdas , por erosão. Bragantia, Campinas, 9: 147-55, 1949.

BERTONI, J. \& PASTANA, F.I. Relação chuvas perdas por erosão em diferentes tipos de solo. Bragantia, Campinas, 23: 311,1964 .

BISCAIA, R.C.M.; RUFINO, R.L.; HENKLAIN, J.C. Cálculo da erodibilidade de dois solos do Estado do Paraná. Revista Brasileira de Ciência do Solo, Campinas, 5: 183-186. 1981. BROWINNING, J.; PARISH, C.L.; GLASS, J.A. A method for determining the use and limitation of rotation and conservation practices in control of soil erosion in Iowa. Journal of the Amererican Society of Agronomy, Madison, 39: $65-73,1947$.

CABEDA, M.S.V. Computation of storm EI value. West Lafayette, Purdue University, 1976. 6p.

CHAVES, I.B. de \& DINIZ, E. J. Erosividade das chuvas no Estado da Paraiba. In: ENCONTRO NACIONAL DE PESQUISA SOBRE CONSERVAÇÃO DO SOLO, 3, Recife, 1981. Anais. Recife, SBCS; UFPE; SUDENE; IPA, 1981. p. 136-147. 
CAMPOS FILHO, O.R.; SILVA, I.F. da.; ANDRADE, A.P. de.; LEPRUN, J.C. Avaliação da erosividade e erodibilidade do agreste pernambucano. In: CONGRESSO BRASILEIRO DE CONSERVAÇÃO DO SOLO, 5, Porto Alegre, 1984. Resumos. Porto Alegre, SBCS, 1984. p. 54 .

CARTER, C.E.; GREER, J.D.; BRAUD, H.J.; FLOYD., J.M. Raindrop characterististics in South Central United States. Transation of the ASE St Joseph, 17: 1033-7, 1974 .

CARVALHO, M.P. Erosividade da chuva: Distribuição e correlação com as perdas de solo de Mococa-SP. Piracicaba, 1987. 104p. (Mestrado - Escola Superior de Agricultura "Luiz de Queiroz" - USP).

COGO, N.P.; DREWS, C.R.; GIANELLO, C. Índice de erosividade das chuvas dos municipios de Guaíba, Ijuí e Passo Fundo, no Estado do Rio Grande do Sul. In: ENCONTRO NACIONAL DE PESQUISA SOBRE CONSERVAÇÃO DO SOLO, 2, Passo Fundo, 1978 Anais. Passo Fundo, CNTRIGo; EMBRAPA; SNLCS, 1978. p. $145-152$.

DEDECEK, R.A. Capacidade erosiva das chuvas de Brasilia-DF. In: ENCONTRO NACIONAL DE PESQUISA SOBRE CONSERVAÇÃO DO SOLO, 2, Passo Fundo, 1978. Anais. Passo Fundo, CNTRIGo; EMBRAPA; SNLCS, 1978. p. 157-61.

ELLISON, W.D. Studeis of raindrop erosion. Agricultural Engineering, St. Joseph, 28: 131-6, 1944. 
FOSTER, G.R. et alii. Conservsion of the Universal Soil Loss

Equation the SI metric units. Journal of soil and water Conservation, Baltimore, 36:355-9, 1981 .

FOSTER, G.R.; LOMBARDI NETO, F.; MOLDENHAUER, W.C.

Evaluation of rainfall-runoff erosivity factores for individual storms. Transactions of de ASAE, St. Joseph, $25: 124-9,1982$.

GRAYBILL, F.A. An introdution to linear statistical model. 、 New York, McGrawHil1, 1961. 684 p. GREER, J.D. Effect of excessive-rate rainstorms on erosion. Journal of soil and Water Conservation, Baltimore, 26: p. $196-7,1971$.

HUDSON, N.W. Rain drop size in higt intensity storm. Rhodesian Journal of Agricultural Research, Salisbury, $1: 6-11,1963$

HUDSON, N.W. Soil Conservation. Ithaca, Cornell University Press, 1973. 320 p.

HUDSON, N.W. Soil Conservation. 2. ed. Ithaca, Cornell University Press, 1981. 324 p.

KINNELL, P.I.A. The problem of assessing the erosive power of rainfall form meteorological observation. Soil science Society of American Proceedings, 37: 617-21, 1973. LAGO, J.C. Erosividade das chuvas de Pelotas-RS. In: ENCONTRO NACIONAL DE PESQUISA SOBRE CONSERVAÇÃO DO SOLO, 5, Porto Alegre, 1984. Resumos. Porto Alegre, SBCS, 1984 . p. 72. 
LAL, R. Soil erosion on Alfisol in Western Nigéria, III. Effects of rainfall characteristics. Geoderma, Amsterdam, $16: 389-401,1976$.

LAWS, J.O. \& PARSONS, D.A. Recent studies in raindrop and erosion. Agricultural Engeneering, St. Joseph, 21: 431-3, 1940 .

LAWS, J.O. \& PARSONS, D.A. the relation of raindrop size to intensity. American Geophysical Union Transctions, - Washington, 24: 452,. 1943.

LEPRUN, J.C. A erosão, a conservação e o manejo do solo no Nordeste brasileiro; Balanço, diagnóstico e novas linhas de pesquisa. Recife, SUDENE; ORSTOM, 1981. 107P.

LEPRUN, J.C. Primeira avaliação do diâmetro de gotas de chuva no Nordeste. In: ENCONTRO NACIONAL DE PESQUISA SOBRE CONSERVAÇÃO DO SOLO, 5, Porto Alegre, 1984. Resumos. Porto Alegre, SBCS, p. 73.

LOMBARDI NETO, F. \& PASTANA, I.F. Relação chuva perdas por erosão. Bragantia, Campinas, 31: 227-34, 1972.

LOMBARDI NETO, F. Rainfall exosivity. Its distribuition and relation with soil loss an Campinas-Brasil. West Lafayette, 1977. 53p. (M.Sc. Purdue University)

LOMBARDI NETO, F. \& MOLDENHAUER, W.C. Erosividade da chuva; sua distribuição e relação com as perdas de solo em Campinas-SP. In: ENCONTRO NACIONAL DE PESQUISA SOBRE CONSERVAÇÃO DO SOLO, 3, Recife, 1981. Anais. Recife, SBCS, 1981. p. 158 . 
LOW, F.K.A. Soil erosion due to rainfall in Peru. In: CONGRESSO PANAMERICANO DE CONSERVAÇÃO DO SOLO, 1 , São Paulo, 1966. Anais. São Paulo, Secretaria Estadual do Estado de São Paulo,1966. p. 211-219.

MARQUES, J.O.A. Determinação de perdas por erosão. Archivo Fitotecnico del Uruguai, Montevideo, 4: 505-556, 1951. MEDINA, B.F. \& OLIVEIRA JUNIOR, R.C. de. Aplicabilidade de alguns índices erosivos em Latossolo Amarelo de Manaus-Am. Revista brasileira de Ciência do Solo, Campinas, 11: 67$79,1987$.

MORAIS, L.F.B. Indices de erosividade de chuvas naturais correlacionadas com perdas de solo em três locais do Rio Grande do Sul. Santa Maria, 1986. 108p. (Mestrado Universidade Federal de Santa Maria).

MUSGRAVE, G.W. The quantitative evaluation of factors in water erosion - A first aproximation. Journal of Soil and Water Conservation, Ankeny, 2: 133-8, 1947.

PEREIRA, H.H.G. Indice de erosividade de chuvas: distribuição e relações com a precipitação em Piracicaba-SP: Piracicaba, 1983. 70 p. (Mestrado-Escola Superior de Agricultura "Luiz de Queiroz"/USP).

ROSE, C.W. Soil detachment caused by rainfall. Soil science, Baltimore, $89: 28-35,1960$. 
ROTH, C.H.; HENKLAIN, J.C.; FARIAS, G.S. de. Avaliação preliminar do tamanho de gotas de chuva natural, dos simuladores de Swanson e Goettingen para o Norte do Paraná. In: ENCONTRO NACIONAL DE PESQUISA SOBRE CONSERVAÇÃO DO SOLO, 5, Porto Alegre, 1984 . Resumos. Porto Alegre, SBCS, 1984. p. 71.

SCHWAB, G.O.; FREVERT, R.K.; EDMINSTE, T.W.; BARNES, K.K. Soil and Water Conservation Engineering. 2. ed. New York, . Jonh Wiley, 1981. 525p.

SMITH, D.D. Interpretation of soil conservation data for field use. Agricultural Engineering, St. Joseph, 22: 1735,1941

SMITH, D.D. \& WISCHMEIER, W, H. Rainfall erosion. Advance in Agronomy, New York, 14: 109-148, 1962.

SOUZA PINTO, N.L. de. S, i HOLTZ, J.A.M.; GOMIDE, F.L.S.i Hidrologia Básica. São Paulo, Edgard Blucher, 1976. 278p. STOCKING, M.A. \& ELWELL, H.A. Prediction of subtropical storm soil losses form field plot studies. Agricultural meteorology, Amsterdam, 12: 193-201, 1973.

WISCHMEIER, W.H. \& SMITH, D.D. rainfall energy and its relationschip to soil loss. Transaction American Ceophysical Union, Washington, 39: 285-91, 1958.

WISCHMEIER, W.H. A rainfall erosion index for a universal soil-loss equation. Soil science society of American Proceedings, Madison, 23: 246-49, 1959. 
WISCHMEIER, W.H. Rainfall erosion potential. Agricultural Engineering, St. Joseph, 43: 212-5, 225, 1962.

X WISCHMEIER, W.H. \& SMITH, D.D. Predicting rainfall erosion losses; a guide to conservation planning. Washington, USDA, 1978. 58p. (Agricultural Handbook, 537).

ZANCHI, C. \& TORRI, D. Evaluation of rainfall energy in Central Italu. In: DE BOODT, M. \& GABRIELS, D., ed. Assecessement of erosion. Chichester, John Wiley, 1980. $\therefore 563 \mathrm{p}$.

ZINGG, A.W. Degree and Length slope as it effect soil loss in run-off. Agricultutal Engineering, 21: 59, 1940 . 
A $P$ E $\quad \hat{E}$ N D I C E

1. Fatores de frequência (K) utilizados para o cálculo do valor teórico de um evento hidrológico qualquer e correspondente a um determinado período de retorno (Equação 13).

\begin{tabular}{|c|c|c|c|c|c|}
\hline Csa & \multicolumn{4}{|c|}{ Período de Retorno } & C.V \\
\hline \multirow[t]{2}{*}{1,7} & 2 & 5 & 20 & 100 & 0,51 \\
\hline & $-0,22$ & $-0,65$ & $+1,89$ & $+3,40$ & \\
\hline
\end{tabular}

Fonte: Souza Pinto et alii (1976)

Exemplo 1: Para o período de retorno de 100 anos.

$$
\begin{aligned}
& \mathrm{X}_{\mathrm{C}}=2086(1+0,51 \cdot 3,40) \\
& \mathrm{X}_{\mathrm{C}}=5703 \mathrm{MJ} \cdot \mathrm{mm} / \mathrm{ha} \cdot \mathrm{h} \cdot \text { ano }
\end{aligned}
$$

Exemplo 2: Para o período de retorno de 20 anos.

$$
\begin{aligned}
& x_{C}=2086(1+0,51 \cdot 1,89) \\
& x_{C}=4097 \mathrm{MJ} \cdot \mathrm{mm} / \mathrm{ha} \cdot \mathrm{h} \cdot \text { ano }
\end{aligned}
$$

Exemplo 3: Para o período de retorno de 5 anos.

$$
\begin{aligned}
& x_{C}=2086(1+0,51 \cdot-0,65) \\
& X_{C}=2777 \text { MJ.mm/ha.h.ano }
\end{aligned}
$$

Exemplo 4: Para o período de retorno de 2 anos.

$$
\begin{aligned}
& \mathrm{x}_{\mathrm{C}}=2086(1+0,51 \cdot-0,22) \\
& \mathrm{x}_{\mathrm{C}}=1859 \mathrm{MJ} \cdot \mathrm{mm} / \mathrm{ha} \cdot \mathrm{h} \cdot \text { ano }
\end{aligned}
$$

